\title{
Korelasi Konsep Kerajaan Allah dan Pemuridan dalam Injil Matius bagi Pemuridan Masa Kini
}

\author{
Sandra Wisantoso \\ Sekolah Tinggi Teologi SAAT, Malang \\ Korespondensi: sandra.wisantoso@seabs.ac.id
}

\begin{abstract}
Abstrak: Di dalam gereja/persekutuan terjadi gejala banyak orang yang mengaku Kristen, tetapi sedikit yang mau dimuridkan. Namun, faktor penyebab utama masalah pemuridan di gereja justru berasal dari dalam kekristenan sendiri. Ada dikotomi antara "menjadi orang percaya" dan "menjadi murid" yang mengakibatkan orang-orang Kristen tidak lagi menjadikan Kristus sebagai Tuhan dan Raja yang harus disembah dan ditinggikan di dalam seantero kehidupan mereka. Akibatnya, pemuridan hanya menjadi sekadar program yang mentradisi dan tidak lagi menolong orang percaya bertumbuh menjadi murid Kristus yang hidup serupa dengan-Nya. Solusi bagi permasalahan pemuridan ini terletak pada strategi pemuridan yang Yesus kerjakan, yaitu di dalam kerangka atau dimensi Kerajaan Allah. Kerajaan Allah dan pemuridan merupakan dua topik besar dan signifikan di dalam Injil Matius. Korelasi antara konsep Kerajaan Allah dengan pemuridan dalam Injil Matius adalah pemuridan merupakan sebuah proses untuk membawa semua orang menjadi murid Yesus, yaitu warga Kerajaan Allah, yang tunduk di bawah pemerintahan Allah dan taat melakukan kehendak-Nya. Korelasi inilah yang dapat menjadi jawaban bagi permasalahan pemuridan yang terjadi di dalam gereja/persekutuan pada saat ini.
\end{abstract}

Kata-kata kunci: Kerajaan Allah, Pemuridan, Murid, Injil Matius

Abstract: In the church or fellowship there are symptoms of many people claiming to be Christians, but few want to be discipled. However, the main contributing factor to the problem of discipleship in the church comes from within Christianity itself. There is a dichotomy between "being a believer" and "being a disciple" that causes Christians to no longer make Christ as Lord and King who must be worshiped and exalted throughout their lives. As a result, discipleship only becomes program and tradition but no longer helps believers grow into disciples of Christ who live like Him. The solution to the problem of discipleship lies in the discipleship strategy that Jesus worked on, namely within the framework or dimensions of God's Kingdom. The kingdom of God and discipleship are two big and significant topics in the Gospel of Matthew. The correlation between the concept of the kingdom of God and discipleship in the Gospel of Matthew is discipleship as a process to bring all people into disciples of Jesus, the citizens of the kingdom of God, who are subject to God's rule and obedient to do His will. This correlation can be the answer to the problem of discipleship that is happening in the church or fellowship at this time.

Keywords: Kingdom of God, Discipleship, Disciple, The Gospel of Matthew 


\section{PENDAHULUAN}

Pada masa kini banyak orang yang mengaku Kristen, tetapi sedikit yang mau menjadi murid Kristus. Demikian pula banyak orang Kristen yang menyadari pentingnya bertumbuh menjadi serupa Kristus namun hanya sedikit sekali yang sungguh-sungguh terlibat di dalam proses pemuridan. Kenyataan ini terlihat dalam riset Barna beberapa tahun terakhir ini. Dari survei yang diadakan pada awal tahun 2015, Barna mendapati bahwa ada $43 \%$ responden yang mengatakan dengan tepat bahwa pertumbuhan rohani berarti bertumbuh menjadi serupa dengan Kristus. ${ }^{1}$ Bahkan dari survei tersebut juga ditemukan bahwa $52 \%$ responden yang rutin beribadah di gereja selama enam bulan terakhir mengatakan gereja mereka sudah berusaha melakukan yang terbaik untuk menolong jemaat bertumbuh. Namun demikian, sangat disayangkan bahwa hanya 20\% responden yang sungguh-sungguh terlibat di dalam kegiatan pemuridan di gereja, seperti mengikuti Sekolah Minggu dewasa atau persekutuan, bertemu dengan mentor, dan mempelajari Alkitab secara bersama-sama di dalam kelompok.

Tanpa menyepelekan tantangan-tantangan dari luar, sumbangsih terbesar permasalahan pemuridan masa kini sebenarnya berasal dari dalam kekristenan sendiri. Akar permasalahannya terletak pada konsep Kerajaan Allah yang salah kaprah. Bagi sebagian orang Kristen pada hari ini, Kerajaan Allah adalah utopia surga nun jauh di sana yang akan menjadi tujuan orang percaya kelak dan tidak ada sangkut pautnya dengan kehidupan saat ini; bukan realitas pemerintahan Allah yang universal atas seluruh jagat raya di dalam pribadi Kristus sebagai Tuhan. Dengan pemahaman Kerajaan Allah yang demikian, orang Kristen pada masa kini merasa sudah cukup hanya dengan mengaku percaya kepada Yesus Kristus karena baginya hal itu sudah menjadi jaminan untuk masuk surga. Mengaku percaya kepada Yesus Kristus tidak disertai

\footnotetext{
1"New Research on the State of Discipleship," Barna Group, diakses 1 Juni 2019. https://www.barna.com/ research/new-research-on-the-state-of-discipleship.
}

dengan komitmen menjadi murid Kristus. Dallas Willard mengatakan, "The problem is that we have been obsessed with this idea that the real issue is 'making the cut' to heaven."

Dikotomi antara "menjadi orang percaya" dan "menjadi murid" mengakibatkan orangorang Kristen tidak lagi menjadikan Kristus sebagai Penguasa utama yang harus disembah dan ditinggikan di dalam seantero kehidupan mereka. Setelah pertobatannya, seorang percaya tidak lagi dituntut dan menuntut dirinya sendiri untuk memiliki komitmen mengikut Kristus sebagai murid-Nya yang hidup taat kepada-Nya. Willard mengatakan, "We have taken the discipleship out of conversion." $3 \mathrm{Di}$ dalam gereja/persekutuan, menjadi murid adalah tingkatan yang lebih tinggi sesudah menjadi orang percaya. Artinya orang percaya dan murid Kristus adalah dua hal yang berbeda; seseorang dapat menjadi orang percaya tanpa menjadi murid Kristus.

Dengan demikian, tidaklah mengherankan jika pada zaman sekarang ini semakin sulit mencari orang Kristen yang sungguh-sungguh berkomitmen untuk menjadi murid Kristus. Dikotomi ini menyebabkan pemuridan hanya menjadi salah satu program/kegiatan dari sekian banyak program/kegiatan lain yang ditawarkan. Pemuridan hanya ditempatkan pada daftar aktivitas, tetapi tidak menjadi satu-satunya tujuan/fokus yang diutamakan. ${ }^{4}$ Dengan demikian, tidaklah mengherankan jika pemuridan hanya menjadi sekadar program yang mentradisi dan telah kehilangan esensinya-menolong orang bertumbuh menjadi murid Kristus yang hidup serupa dengan-Nya.

${ }^{2}$ Dallas Willard, "Rethinking Evangelism," DWillard. org, diakses 1 Juni 2019, http://www.dwillard.org/articles/ individual/rethinking-evangelism.

${ }^{3}$ Ibid.

${ }^{4}$ Bill Hull mengatakan, "The trap is to allow disciple making to be put on the acitivity list rather than purpose list" (Building High Commitment in a Low Commitment World [Grand Rapids: Revell, 1995], 74). 
Pemuridan semacam ini hanya akan menghasilkan orang-orang Kristen yang hidup dalam zona kenyamanannya sendiri, tidak peduli dengan keadaan dunia ini dan mengabaikan tanggung jawab mereka untuk menerangi dan menggarami dunia ini. Solusi bagi permasalahan pemuridan masa kini adalah dengan menerapkan kembali strategi pemuridan yang Yesus kerjakan, yaitu di dalam kerangka atau dimensi Kerajaan Allah.

Kerajaan Allah dan pemuridan merupakan dua topik besar dan signifikan di dalam Injil Matius. Signifikansi topik Kerajaan Allah dalam Injil ini dapat dilihat dari banyaknya penggunaan kata "Kerajaan Allah" atau "Kerajaan Surga" dalam seluruh Injil ini. Mengenai signifikansi topik pemuridan di dalam Injil ini dapat dilihat dari penekanan yang Matius berikan kepada peristiwa-peristiwa di mana Yesus memanggil, mengajar dan mengutus murid-murid-Nya untuk meneruskan pengajaran-Nya. Karena penekanan inilah, Injil Matius dapat dikatakan sebagai

${ }^{5}$ Dalam bahasa aslinya kata "kerajaan" ( $\left.\beta \alpha \sigma i \lambda \varepsilon i ́ \alpha\right)$ muncul lima puluh lima kali di dalam Injil Matius dengan perincian sebagai berikut (Joel B. Green, "Kingdom of God/Heaven," dalam Dictionary of Jesus and the Gospels, ed. Joel B. Green, Jeannine K. Brown, Nicholas Perrin, ed. ke-2 [Downers Grove: InterVarsity, 2013], 473). Kata ini muncul tiga puluh dua kali di dalam frasa "Kerajaan

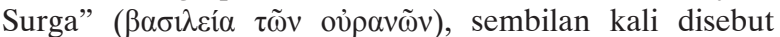
hanya basileia tanpa keterangan (Mat. 4:23; 6:33; 8:12; 9:35; 13:19, 38; 21:43; 24:14; 25:34), tiga kali muncul dalam

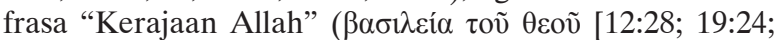
21:31]), tiga kali disebut dalam konteks sebagai kerajaan Bapa $(6: 10 ; 13: 43 ; 26: 29)$, dua kali disebut dalam konteks kerajaan Anak Manusia $(13: 41 ; 16: 28)$, satu kali disebut dalam konteks kerajaan Yesus (Mat. 20:21) and lima kali mengacu kepada kerajaan-kerajaan lainnya (4:8; 12:25, 26; 24:7 [2 kali]). Selain itu, signifikansi konsep kerajaan Allah dalam Injil Matius juga terlihat dari penyebarannya yang strategis di sepanjang injil ini (ibid.). Penggunaan bahasa Raja atau kerajaan muncul di dalam 25 pasal dari keseluruhan 28 pasal. Pelayanan Yohanes Pembaptis, Yesus dan para murid dimulai dengan proklamasi yang sama: "Kerajaan Sorga sudah dekat!" (3:2; 4:8; 10:7). Matius merangkum seluruh berita dan pengajaran Yesus dengan frasa "Injil Kerajaan" (4:23; 9:35; 24:14) yang juga harus diproklamasikan kepada semua bangsa di seluruh dunia. Melihat banyaknya penggunaan frasa ini dalam Injil Matius, Kingsbury menyimpulkan bahwa "the single most comprehensive concept in the first Gospel is without doubt that of the Kingdom of Heaven" (Jack Dean Kingsbury, Matthew: Structure, Christology, Kingdom (Minneapolis: Fortress, 1989), 128. buku panduan pemuridan. ${ }^{6}$ Artikel ini secara khusus akan menyoroti korelasi antara dua topik ini dalam sebuah tesis yang dapat dinyatakan sebagai berikut: korelasi antara konsep Kerajaan Allah dengan pemuridan dalam Injil Matius adalah pemuridan merupakan sebuah proses untuk membawa semua orang menjadi murid Yesus, yaitu warga Kerajaan Allah, yang tunduk di bawah pemerintahan Allah dan taat melakukan kehendak-Nya.

Korelasi inilah yang dapat menjadi jawaban bagi permasalahan pemuridan yang terjadi di dalam gereja/persekutuan pada saat ini. Korelasi ini akan dijabarkan dengan menganalisis narasi-narasi di dalam Injil Matius dengan mengikuti struktur seperti yang diusulkan oleh Christopher R. Smith dalam Tabel 1 (dapat dilihat di halaman 48). Smith mengelaborasi struktur lima bagian dari B.W. Bacon ${ }^{7}$ yang selama ini sangat berpengaruh dalam studi Injil Matius, dengan memperlihatkan makna dan karakteristik Kerajaan Allah di dalam setiap bagiannya.

\section{PENDAHULUAN: SILSILAH YESUS (1:1-17)}

Matius mengawali rangkaian injilnya dengan catatan mengenai silsilah Yesus (1:1-17). Rangkaian silsilah ini menunjukkan adanya suatu perkembangan sejarah Israel yang semakin memuncak pada kedatangan Yesus sebagai Mesias Rajani. Ia adalah pemenuhan janji Allah kepada Abraham dan

${ }^{6}$ M.J. Wilkins menunjukkan beberapa faktor yang memperlihatkan intensi Matius untuk memaksudkan injilnya sebagai panduan pemuridan ("Disciples and Discipleship," dalam Dictionary of Jesus and The Gospels, ed. Joel B. Green, Jeannine K. Brown, dan Nicholas Perrin, ed. ke-2 (Downers Grove: InterVarsity, 2013), 208. Pertama, khotbah, pengajaran atau percakapan utama dalam injil ini ditujukan secara khusus kepada para murid (Mat. 5:1$2 ; 10: 1-2 ; 13: 10 ; 18: 1 ; 23: 1-3)$. Kedua, perkataan-perkataan Yesus yang ditujukan kepada para murid adalah pengajaran tentang pemuridan. Ketiga, para murid secara umum digambarkan secara positif (mengerti pengajaran Yesus) namun tetap realistis (ada ketidakmengertian). Keempat, para murid dipanggil, dilatih dan diutus untuk melaksanakan mandat memuridkan orang lain (28:19).

${ }^{7}$ B.W. Bacon, "The Five Books of Matthew Against the Jews," Expositor 15 (1918), 56-66 dan juga Studies in Matthew (New York: Holt, 1930). 
Tabel 1 Struktur Injil Matius menurut Christopher R. Smith

\begin{tabular}{|c|c|c|}
\hline Introduction & Genealogy (1:1-17) & \\
\hline The foundations of the kingdom & $\begin{array}{l}\text { First Narrative } \\
(1: 18-4: 25)\end{array}$ & $\begin{array}{l}\text { First Discourse } \\
(5: 1-7: 29)\end{array}$ \\
\hline The mission of the kingdom & $\begin{array}{l}\text { Second Narrative } \\
(8: 1-9: 38)\end{array}$ & $\begin{array}{l}\text { Second Discourse } \\
(10: 1-42)\end{array}$ \\
\hline The mystery of the kingdom & $\begin{array}{l}\text { Third Narrative } \\
(11: 1-13: 9)\end{array}$ & $\begin{array}{l}\text { Third Discourse } \\
(13: 10-53)\end{array}$ \\
\hline The family of the kingdom & $\begin{array}{l}\text { Fourth Narrative } \\
(13: 54-17: 27)\end{array}$ & $\begin{array}{l}\text { Fourth Discourse } \\
(18: 1-35)\end{array}$ \\
\hline The destiny of the kingdom & $\begin{array}{l}\text { Fifth Narrative } \\
(19: 1-23: 39)\end{array}$ & $\begin{array}{l}\text { Fifth Discourse } \\
(24: 1-25: 46)\end{array}$ \\
\hline Conclusion & $\begin{array}{l}\text { Passion Narrative } \\
(26: 1-28: 20)\end{array}$ & \\
\hline
\end{tabular}

Sumber: Christopher R. Smith, “Literary Evidence of a Fivefold Structure in the Gospel of Matthew,” NTS 43 (1997): 540-551.

Daud. Pertama, Yesus menggenapi janji Allah kepada Abraham bahwa melalui keturunannya segala bangsa di bumi akan mendapat berkat. ${ }^{8}$ Kedua, Yesus menggenapi janji Allah kepada Daud bahwa kerajaannya akan kekal. Ia adalah Mesias, Raja Israel, yang selama ini dinantikan oleh bangsa Yahudi. ${ }^{9}$

Ketiga, melalui penyebutan lima nama perempuan secara khusus (Tamar, Rahab, Rut, Batsyeba istri Uria dan Maria), Matius ingin memperjelas bahwa, selain lahir dari keturunan Abraham dan Daud, Yesus sesungguhnya tidak berasal dari dunia ini. W.J.C. Weren mengatakan bahwa Maria melanjutkan peran

${ }^{8}$ Frasa "anak Abraham" menunjukkan bahwa Yesus adalah seorang Yahudi keturunan Abraham, yang meneruskan berkat-berkat yang telah dimulai dari Abraham sampai kepada puncaknya bagi segala bangsa (Nancy L. Calvert, "Abraham," dalam Dictionary of Jesus and the Gospels, ed. Joel B. Green dan S. McKnight [Downers Grove: InterVarsity, 1992], 4). Dengan demikian, Yesus merupakan pewaris dari janji Allah kepada Abraham (Kej. 12:3).

${ }^{9}$ Pemberian gelar "Kristus" kepada Yesus menegaskan identitas Yesus sebagai Mesias, yaitu Pribadi yang diurapi Allah. Kingsbury mengatakan, "In describing Jesus as the Messiah, Matthew presents him as the Anointed One, Israel's long-awaited King" (Jack Dean Kingsbury, "The Plot of Matthew's Story," Interpretation 44, no. 4 [1992]: 347). Frasa "anak Daud" menyatakan bahwa Yesus berasal dari keturunan Daud; Dia adalah pewaris yang sah dari takhta Israel (2Sam. 7:12-16). dari keempat wanita sebelumnya ${ }^{10}$ karena memasuki ikatan pernikahan dan melahirkan anak dengan cara yang tidak lazim dan dapat dicurigai sebagai perselingkuhan menurut budaya pada masa itu. ${ }^{11}$ Ketika pembaca injil ini memperhatikan frasa "Maria, yang darinya Yesus dilahirkan" 12 akan bertanya siapakah sesungguhnya ayah Yesus, maka Matius secara implisit ingin menegaskan bahwa Yesus berasal dari Allah sendiri. ${ }^{13}$ Melalui silsilah ini, dapat disimpulkan Matius ingin memperlihatkan bahwa Yesus yang lahir dari garis keturunan Daud dan Abraham sesungguhnya adalah Anak Allah sendiri yang menghadirkan Kerajaan-Nya di bumi ini.

${ }^{10}$ Tamar dan Batsyeba melahirkan anak yang bukan dari suami mereka yang sah. Rahab dan Rut menjadi ibu melalui ikatan pernikahan dengan suami dari bangsa asing.

${ }^{11}$ Wilhelmus J.C. Weren, Studies in Matthew's Gospel: Literary Design, Intertextuality, and Social Setting, Biblical Interpretation Series Volume 130 (Leiden: Brill, 2014), 109-111.

${ }^{12}$ Frasa "yang darinya Yesus dilahirkan" berasal dari

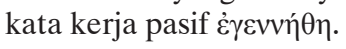

${ }^{13} \mathrm{Hal}$ ini diperjelas kemudian oleh kesaksian malaikat di dalam mimpi Yusuf (1:20). Dalam hal ini penulis kontra dengan kesimpulan Weren yang lebih menekankan peran heroik para wanita tersebut di mata umat Israel daripada peran inisiatif Allah sendiri (Weren, Studies in Matthew, 124). 


\section{FONDASI KERAJAAN ALLAH}

(1:18-7:29)

\section{Narasi Fondasi Kerajaan Allah (1:18-4:25)}

Matius mengawali narasi fondasi Kerajaan Allah dengan narasi kelahiran Yesus (1:1825). Dalam narasi permulaan ini, Matius mengungkapkan bahwa Yesus adalah manifestasi kehadiran Kerajaan Allah di bumi ini. Hal ini dibuktikannya dengan mengutip dari Yesaya 7:14 (1:22-23) yang menyatakan dengan jelas bahwa Yesus adalah Imanuel, Allah yang menyertai kita. Nama Yesus sendiri memiliki arti Allah menyelamatkan ${ }^{14}$ dan ini dipertegas dengan pernyataan, "Dialah yang akan menyelamatkan umat-Nya dari dosa mereka" (1:21). Dua nama ini-Yesus dan Imanuel-mempertegas kehadiran Yesus di bumi sebagai partisipasi aktif Allah di dalam menyelamatkan umat-Nya. ${ }^{15}$

Kehadiran Kerajaan Allah ini menuntut adanya respons dari setiap orang, dan di dalam narasi kelahiran ini, Yusuf adalah orang pertama yang diperhadapkan pada tuntutan ini. Niatnya menceraikan Maria dengan diamdiam diintervensi Allah dengan mengutus seorang malaikat datang kepadanya dalam mimpi. Allah menyatakan kehendak-Nya kepada Yusuf agar ia mengambil Maria sebagai istrinya dan kemudian memberi nama "Yesus" kepada anak yang akan dilahirkan itu. Yusuf, seorang yang sangat taat kepada Taurat, ${ }^{16}$ akhirnya memilih untuk taat kepada

${ }^{14}$ S. Young, "Birth of Jesus," dalam Dictionary of Jesus and The Gospels, ed. Joel B. Green, Jeannine K. Brown, dan Nicholas Perrin, ed. ke-2 (Downers Grove: InterVarsity, 2013), 73.

${ }^{15}$ Margaret Hannan, The Nature and Demands of the Sovereign Rule of God in the Gospel of Matthew, LNTS 308 (New York: T\&T Clark, 2006), 28.

${ }^{16}$ Ketaatan Yusuf kepada hukum Taurat ini diindikasikan oleh karakter Yusuf, yang díkaıs (oleh LAI diterjemahkan "tulus hati" bdk. terjemahan Inggris yang menggunakan kata "righteous" atau "just"). Leon Morris mengatakan, "Joseph, Mary's husband, is called just, which probably means that he was careful in his observance of the law" (The Gospel According to Matthew, Pillar New Testament Commentary [Grand Rapids: Eerdmans, 1992], 27). kehendak Allah. ${ }^{17}$ Ketaatannya ini memperlihatkan bahwa ia adalah seorang murid yang baik, ${ }^{18}$ yang menerima kehadiran Kerajaan Allah dengan taat melakukan kehendak-Nya. Selain Yusuf, Matius juga menunjukkan bahwa orang-orang Majus adalah orang-orang yang juga merespons kehadiran Kerajaan Allah. Mereka mewakili bangsabangsa non-Yahudi yang meskipun tidak memiliki pengetahuan tentang Mesias namun berespons positif terhadap pesan Allah melalui bintang. ${ }^{19}$ Mereka datang dari jauh untuk mencari, menyembah dan memberikan persembahan kepada Raja yang baru lahir (2:11). Mereka pun taat kepada peringatan Allah melalui mimpi (2:12).

Matius melanjutkan narasi fondasi Kerajaan Allah dengan mempresentasikan permulaan pelayanan Yesus yang disandingkan dengan pelayanan Yohanes Pembaptis. Baik Yohanes Pembaptis maupun Yesus menyerukan berita yang sama kepada umat Israel: "Bertobatlah, sebab Kerajaan Sorga sudah dekat!" (3:2; $4: 17) .{ }^{20}$ Frasa $\beta \alpha \sigma \iota \lambda \varepsilon i ́ \alpha \tau \tilde{\omega} v$ oủ $\rho \alpha v \tilde{\omega} v$ (Kerajaan Surga) dalam Injil Matius memang menjadi kekhasan injil ini dibandingkan ketiga injil lainnya yang menggunakan frasa $\beta \alpha \sigma i \lambda$ cía

${ }^{17}$ Ben Witherington III mengomentari narasi Matius ini dengan mengatakan, "The intention of the Evangelist is to paint a picture of a devout Jewish man who is willing to give up what was often perceived to be a Jewish father's great privilege-siring his first-born son-in order to obey God's will (1:24)" ("Birth of Jesus," dalam Dictionary of Jesus and The Gospels, ed. Joel B. Green, Scott McKnight, dan I. Howard Marshall (Downers Grove: InterVarsity, 1992), 62.

${ }^{18}$ Witherington mengatakan, "It is Joseph who is presented to the Evangelist's audience as a model disciple" (ibid.).

${ }^{19}$ Young, "Birth of Jesus," 75.

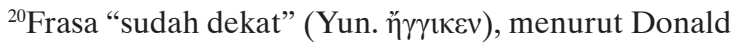
A. Hagner, "refers normally to that which is at the point of arriving. The perfect tense here results in the nuance 'having drawn near and remaining near" (Matthew 1-13, Word Biblical Commentary 33a [Dallas: Word, 1993], 47). Arthur F. Glasser juga menambahkan, "He announced that the Kingdom was no longer solely a future hope but a present reality" (Announcing the Kingdom [Grand Rapids: Baker, 2003], 186). Dengan demikian, dapat dikatakan bahwa Kerajaan Allah "sudah tiba" melalui pelayanan Yohanes sebagai pembuka jalan bagi Mesias, dan terlebih lagi melalui pelayanan Yesus sebagai Sang Mesias itu sendiri yang menggenapinya. 


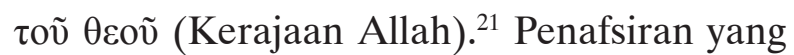
umum terhadap keunikan Matius ini adalah bahwa "surga" adalah kata pengganti untuk menghormati kata "Allah" sehingga "Kerajaan Surga" tidaklah berbeda dengan "Kerajaan Allah." 22 Namun, penjelasan yang seperti ini cenderung kurang dapat menjelaskan signifikansi penggunaan kata "surga" oleh Matius. J. Pennington menyelidiki bahwa Matius menggunakan frasa "Kerajaan Surga" karena dipengaruhi oleh Daniel 2-7 dengan sentralnya adalah Daniel 4:1-37, untuk mempertegas kontras perbedaan kualitas antara kerajaan dunia dengan Kerajaan Surga. ${ }^{23}$ Matius memilih frasa ini untuk menekankan bahwa kerajaan ini memiliki asal-usul, atribut dan karakter surgawi, yaitu takhta Allah itu sendiri. ${ }^{24}$ Selain dalam bentuk proklamasi, Kerajaan Allah juga dihadirkan melalui peristiwa pembaptisan Yesus oleh Yohanes. Pengurapan Roh Allah dan konfirmasi suara dari surga (3:16-17) semakin mempertegas peran Yesus sebagai pribadi yang menghadirkan Kerajaan Allah dengan otoritas untuk berbicara dan bertindak mewakili Allah. ${ }^{25}$

Proklamasi Kerajaan Allah yang telah diserukan Yohanes dan Yesus harus direspons dengan pertobatan, yaitu kerendahan hati dan kerelaan untuk menundukkan diri di bawah otoritas Kerajaan Allah dan menghasilkan buah berupa ketaatan melakukan

\footnotetext{
${ }^{21}$ Green, "Kingdom of God/Heaven," 473.
}

${ }^{22}$ John P. Meier mengatakan bahwa kata "surga" merupakan "a respectful Semitic circumlocution for God" ("Matthew, Gospel of," dalam Anchor Bible Dictionary 4, ed. David Noel Freedman [New York: Double Day, 1992], 638).

${ }^{23}$ Tesis Jonathan T. Pennington ini diuraikan dalam bukunya Heaven and Earth in the Gospel of Matthew, NovTSup 126 (Leiden: Brill, 2007), khususnya bab 11-12.

${ }^{24}$ Dalam konteks narasi fondasi kerajaan ini, Matius mengontraskan Kerajaan Surga dengan kerajaan dunia ini (4:8) untuk semakin menonjolkan sifat dan latar belakang surgawi dari kerajaan Allah (ibid., 298).

${ }^{25}$ Craig S. Keener berkata bahwa melalui peristiwa pembaptisan Yesus ini, para pembaca Matius dapat menyimpulkan bahwa "Jesus is the ultimate ruler who will usher in justice and peace" (The Gospel of Matthew: A Socio-Rhetorical Commentary [Grand Rapids: Eerdmans, 2009], 135).
kehendak-Nya (3:8). Selain penduduk dari Yerusalem, seluruh Yudea dan daerah sekitar Yordan yang datang mengaku dosa dan dibaptis, datang pula orang-orang Farisi dan Saduki untuk melihat peristiwa fenomenal (3:5-7). Namun, tujuan kedatangan mereka bukan untuk bertobat, mengaku dosa dan dibaptis; melainkan hanya ingin melihat peristiwa apa yang sebenarnya sedang terjadi. ${ }^{26}$ Sikap orang-orang Farisi dan Saduki ini secara tidak langsung memperlihatkan penolakan mereka terhadap Kerajaan Allah (3:712). Berbeda dengan sikap mereka, Yesus datang atas inisiatif-Nya sendiri untuk dibaptis oleh Yohanes (3:13-17). Hal ini menunjukkan ketaatan Yesus kepada kehendak Allah, dan ditegaskan kembali melalui jawaban-Nya sebagai respons terhadap keengganan Yohanes: "Biarlah hal itu terjadi, karena demikianlah sepatutnya kita menggenapkan seluruh kehendak Allah" (3:15). ${ }^{27}$ Yohanes pun membaptis Yesus sesuai dengan permintaan-Nya. Luz mengatakan, "John and Jesus thus both fulfil the stipulations of 'righteousness'.... John does so by baptizing Jesus, Jesus by humbly submitting to baptism." 28

Ketaatan Yesus kepada kehendak Allah juga diungkapkan Matius melalui kisah pencobaan di padang gurun (4:1-11). Melalui kisah ini,

${ }^{26} \mathrm{Hal}$ ini diindikasikan dengan kalimat dalam bahasa

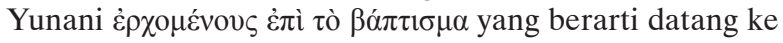
baptisan, bukan datang untuk dibaptis. Hal ini menunjukkan bahwa orang-orang Farisi dan Saduki tersebut sebenarnya datang bukan untuk ikut dibaptis, melainkan untuk mengamati dan menyelidiki peristiwa itu.

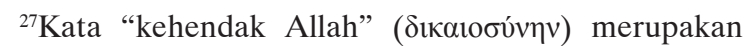
kata kunci di dalam Injil Matius. Kata ini digunakan sebanyak tujuh kali di dalam keseluruhan injil ini. William Loader mengatakan bahwa kata ini merupakan "key theme in Matthew, precisely because it expresses this total commitment to doing God's will" (Jesus and the Fundamentalism of His Day [Grand Rapids: Eerdmans, 2001], 76). Hagner juga mengatakan bahwa kata ini menunjukkan "the accomplishing of God's will in its fullness" (Matthew 1-13, 56). Dengan demikian, dapat disimpulkan bahwa baptisan yang Yesus terima tidak menunjuk kepada pertobatan dari dosa sebagaimana yang berlaku untuk orang-orang lain; melainkan menunjuk kepada ketaatan Yesus di dalam melakukan kehendak Allah bagi diri-Nya, yaitu menggenapi rencana keselamatan Allah.

${ }^{28}$ Ulrich Luz, The Theology of The Gospel of Matthew (Cambridge: Cambridge University Press, 1995), 35-36. 
Matius ingin mengontraskan ketaatan Yesus dengan ketidaktaatan Israel sehingga memperlihatkan Yesus sebagai Israel sejati yang taat kepada kehendak Allah. ${ }^{29}$ Ketaatan Yesus ini membuktikan diri-Nya sebagai Anak Allah sejati yang tunduk sepenuhnya kepada kehendak Bapa-Nya. ${ }^{30}$ Dengan demikian, Ia juga menjadi teladan murid yang sejati, yang taat sepenuhnya kehendak Allah.

Proklamasi kehadiran Kerajaan Surga oleh Yesus segera ditindaklanjuti dengan panggilan-Nya kepada beberapa nelayan Galilea untuk menjadi murid-murid-Nya yang pertama (4:18-22). Panggilan Kerajaan Allah yang Yesus berikan kepada para nelayan Galilea ini telah menghadapkan mereka pada tuntutan untuk memberikan respons, yaitu menerima atau menolak panggilan tersebut. Para nelayan tersebut memberikan respons yang tepat: mereka menerima panggilan kerajaan Allah dengan cara meninggalkan jala dan perahu mereka untuk mengikut Yesus. ${ }^{31}$ Respons para nelayan ini menunjukkan bahwa mereka memiliki kualitas seorang murid, yaitu "the leaving behind of past preoccupations and the unhesitating and unconditional response of following." ${ }^{2}$ Setelah Yesus memanggil muridmurid-Nya yang pertama, Ia mulai berkeliling seluruh Galilea (4:23-25). Tiga hal yang Yesus lakukan dalam pelayanan-Nya adalah mengajar, memberitakan Injil Kerajaan Allah dan menyembuhkan segala penyakit dan

${ }^{29}$ M.J. Wilkins berkata, "The temptations reenact Israel's history, but victoriously. Neither the nation Israel nor Moses the leader of the nation successfully passed the tests in the wilderness. Jesus now fulfills where they failed" ("Temptation of Jesus," dalam Dictionary of Jesus and The Gospels, ed. Joel B. Green, Jeannine K. Brown, dan Nicholas Perrin, ed. ke-2 [Downers Grove: InterVarsity, 2013], 955).

${ }^{30}$ Jack D. Kingsbury mengatakan, "Unlike Israel son of God, Jesus Son of God is prefect in his devotion, or obedience, to God, his Father" (Matthew as Story [Philadelphia: Fortress], 53).

${ }^{31}$ Tindakan ini menunjukkan bahwa mereka meninggalkan segala sesuatu yang mereka miliki untuk mengikut Yesus. Hal ini selaras dengan makna yang terkandung di dalam kata "mengikut," yaitu "self-commitment in a sense

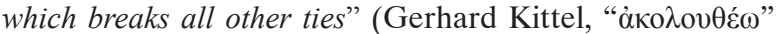
dalam TDNT vol. 1, ed. Gerhard Kittel [Grand Rapids: Eerdmans, 1964], 213).

${ }^{32}$ Hagner, Matthew 1-13, 77. kelemahan di antara bangsa itu. Semua pelayanan Yesus ini mengindikasikan bahwa Dia adalah Mesias yang menghadirkan Kerajaan Allah. ${ }^{33}$ Kehadiran Kerajaan Allah di dalam pelayanan Yesus ini direspons dengan baik oleh orang banyak yang berbondong-bondong mengikuti Yesus. ${ }^{34}$

\section{Pengajaran Fondasi Kerajaan Allah (5:1-7:29)}

Matius melanjutkan narasinya dengan mencatat rangkaian pengajaran Yesus yang dikenal dengan sebutan "Khotbah di Bukit." 35 Keseluruhan pengajaran Yesus, yang terdapat dalam khotbah ini berbicara mengenai standar hidup atau perilaku bagi para murid-Nya yang adalah warga Kerajaan Allah. Ia mengawali Khotbah di Bukit dengan menjelaskan delapan kualitas hidup utama yang harus dimiliki oleh setiap warga Kerajaan Allah (5:3-12), yang secara bersamaan juga mengungkapkan berkat Injil bagi setiap warga Kerajaan Allah yang taat menghidupi kualitas hidup tersebut. ${ }^{36}$ Secara keseluruhan kualitas hidup dan berkat yang dicatat dalam Ucapan Bahagia

\footnotetext{
${ }^{33}$ Hannan, The Nature and Demands, 45.
}

${ }^{34}$ Kata "mengikuti" dalam perikop ini juga menggunakan kata Yunani yang sama seperti dalam 4:20, 22. Dari antara orang banyak yang mengikut Yesus, kemungkinan besar ada yang menjadi murid-murid-Nya. Hagner mengatakan, "It is clear among the crowds there were true disciples in addition to the twelve special disciples" (Matthew 1-13, 81).

${ }^{35} \mathrm{Hal}$ ini disebabkan karena berdasarkan catatan Matius, pengajaran Yesus ini diberikan di atas sebuah bukit (5:1). Rudolf Schnackenburg mengatakan bahwa kata "bukit" harus dimengerti secara tipologis: sebagaimana Musa naik ke Gunung Sinai untuk memproklamasikan hukum Allah kepada Israel (Kel. 19:3; 24:18; 34:1-2); demikian pula Yesus naik ke bukit untuk memproklamasikan berita yang dibawa-Nya, yang melampaui hukum yang lama (The Gospel of Matthew [Grand Rapids: Eerdmans, 2002], 46).

${ }^{36}$ Kualitas hidup yang diungkapkan adalah miskin di hadapan Allah (5:3); berdukacita (5:4); lemah lembut (5:5); lapar dan haus akan kebenaran (5:6); murah hati (5:7); suci hati (5:8); membawa damai (5:9); dan dianiaya oleh sebab kebenaran (5:10-12). Adapun berkat-berkat injil yang dijanjikan bagi setiap warga Kerajaan Allah yang taat adalah memiliki Kerajaan Surga (5:3); mendapat penghiburan (5:4); memiliki bumi (5:5); akan dipuaskan (5:6); akan beroleh kemurahan (5:7); akan melihat Allah (5:8); akan disebut anak-anak Allah (5:9); dan memperoleh upah di Surga (5:12). 
tersebut merupakan tanggung jawab dan hak istimewa setiap warga Kerajaan Allah. Selain dipanggil untuk mengejar kualitas hidup yang sesuai dengan Kerajaan Allah, warga Kerajaan Allah juga dipanggil untuk menjadi berkat bagi dunia ini, yaitu dengan menjalankan peranan mereka sebagai garam dan terang dunia (5:13-16). Sama halnya dengan garam yang berfungsi untuk memberi rasa dan mencegah kerusakan, setiap warga Kerajaan Allah juga berfungsi untuk memberi rasa bagi dunia dan mencegah dunia dari kerusakan yang semakin parah. ${ }^{37}$ Kedua panggilan ini-panggilan untuk mengejar kualitas hidup Kerajaan Allah dan panggilan untuk menjadi garam dan terang—-tidak dapat dipisahkan.

Bagian selanjutnya dari Khotbah di Bukit ini (5:17-48) berbicara mengenai tuntutan Yesus terhadap setiap murid-Nya. Menjadi murid Yesus tidak berarti meninggalkan hukum Taurat, melainkan menaati kebenaran hukum Taurat menurut versi yang Yesus ajarkan. ${ }^{38}$ Ia mengajarkan kepada para murid bahwa yang dituntut Kerajaan Allah adalah bentuk ketaatan dengan komitmen yang penuh kepada diri-Nya sebagai pribadi yang telah menggenapi hukum Taurat (5:17) dan pengajaran-Nya yang merupakan penafsiran sejati dan sepenuhnya terhadap hukum Taurat. ${ }^{39}$

${ }^{37}$ R.T. France mengatakan, "Disciples, if they are true to their calling, make the earth a purer and a more palatable place" (Matthew: Evangelist and Teacher [Exeter: Paternoster], 112). Hal ini hanya akan terwujud jika setiap warga Kerajaan Allah memiliki kualitas hidup Kerajaan Allah (5:3-12). Kualitas hidup inilah yang membuat "rasa asin" dari warga Kerajaan Allah tetap terjaga. Garam yang kehilangan rasa asinnya adalah garam yang tidak berguna. Frasa "menjadi tawar" (LAI) berasal dari kata Yunani $\mu \omega \rho \alpha v \theta \tilde{n}$, yang berarti "menjadi bodoh" (Morris, Matthew, 104). France mengatakan, "A foolish disciple has no influence on the world" (Matthew, 112).

${ }^{38}$ Keener mengatakan, "Jesus comes not to abolish the law but to expound its true sense, to fulfil its spirit" (The Gospel of Matthew, 176).

${ }^{39}$ Formulasi kalimat antitesis yang Yesus gunakan, "Kamu telah mendengar yang difirmankan kepada nenek moyang kita . . . tetapi Aku berkata kepadamu. . . ." (5:2122; 27-28; 31-32; 33-34; 38-39; 43-44) menunjukkan bahwa Ia berbicara bukan atas nama Taurat (seperti yang dilakukan para rabi pada zaman itu), bukan atas nama Allah (seperti yang dilakukan para nabi PL) tetapi atas nama-Nya sendiri. Matius memberi penekanan pada kata "Aku" dengan menambah kata
Ketaatan yang Yesus tuntut dari para pengikut-Nya melampaui kesalehan para orang Farisi dan ahli Taurat yang menjalankan Taurat (5:20). Kesalehan yang Yesus tuntut lebih dari sekadar kesalehan formal melainkan "fidelity to God's will on the level of both action and interior dispositions." 40 Karena itu, Yesus menuntut para murid-Nya haruslah sempurna, sama seperti Bapa di surga adalah sempurna

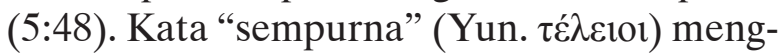
indikasikan hidup yang secara total menyatu dengan kehendak Allah dan dengan demikian mencerminkan karakter-Nya. ${ }^{41}$

Hidup benar yang sesuai dengan tuntutan etika Kerajaan Allah dan melampaui kesalehan para pemimpin agama diperlihatkan dalam aspek-aspek: praktik religius (6:1-18), hati yang murni (6:19-34) serta relasi yang benar dengan Allah dan sesama (7:1-12). Yesus menghendaki semua praktik religius memberi sedekah (6:1-4), berdoa (6:5-14) dan berpuasa (6:15-18) yang dilakukan oleh warga Kerajaan Allah dimotivasi oleh satu kerinduan bahwa Kerajaan Allah yang sudah dihadirkan oleh Yesus itu dapat memerintah sepenuhnya atas seluruh ciptaan (6:10) melalui kehidupan saleh dan pelayanan para murid. Kesalehan yang dilakukan oleh warga Kerajaan Allah itu harus bersumber dari hati yang murni, yaitu tidak terdistraksi oleh apa pun yang dapat mengganggu mereka untuk fokus menaati kehendak Allah, seperti mengumpulkan harta di bumi dan kekhawatiran.

Yesus juga mengajar para murid untuk tidak mengkhawatirkan kehidupannya di bumi ini, dan sebaliknya, berfokus pada mencari Kerajaan Allah dan kebenarannya sebagai bentuk

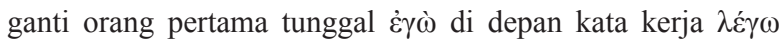
("Aku berkata") untuk menunjukkan bahwa Yesus memiliki otoritas yang melampaui Taurat (Hagner, Matthew 1-13, 111). Jadi, Matius ingin menunjukkan bahwa Yesus adalah pribadi yang melampaui Musa, para nabi dan bahkan melampaui Taurat itu sendiri. Dengan kata lain, Ia adalah pribadi Allah itu sendiri.

\footnotetext{
${ }^{40}$ Hannan, The Nature and Demands, 57.

${ }^{41}$ France, Matthew, 129.
} 
respons kasih mereka kepada Allah (6:33). ${ }^{42}$ Dengan mencari kerajaan Allah dan kebenarannya berarti para murid melihat setiap situasi dalam hidup mereka dari perspektif iman di dalam pemeliharaan Allah. Para murid yang mendahulukan Kerajaan Allah dan kebenarannya akan memiliki sikap tidak menghakimi dan mencari-cari kesalahan orang lain (7:1-5), dan sebaliknya, mereka akan berdoa dengan satu keyakinan kepada Allah yang setia memelihara dan menjawab kebutuhan mereka (7:7-11).

Di akhir penjelasannya mengenai kesalehan warga Kerajaan Allah, Matius menyatakan bahwa seluruh isi hukum Taurat dan kitab para nabi terangkum di dalam kaidah kencana: "Segala sesuatu yang kamu kehendaki supaya orang perbuat kepadamu, perbuatlah demikian juga kepada mereka" (7:12). Ketika para murid Kerajaan Allah memperlakukan sesama dengan sikap hormat dan penuh kemurahan seperti yang diinginkannya bagi dirinya sendiri maka ia sudah memenuhi kehendak Allah yang dinyatakan dalam hukum Taurat (bdk. Im. 19:18; Mat. 22:3540). ${ }^{43}$ Pada saat warga Kerajaan Allah memperlakukan sesama dengan cara seperti ini maka mereka telah meneladani Allah sendiri yang mencurahkan belas kasihan dan kemurahan-Nya baik kepada orang baik maupun orang jahat, orang benar maupun orang yang tidak benar (5:45).

Pengajaran Yesus di bukit ini diakhiri dengan serangkaian metafora yang kontras satu sama lain namun menyatakan kebenaran yang sama. Para murid yang berespons dan berpartisipasi di dalam Kerajaan Allah adalah mereka yang memilih pintu yang sesak daripada pintu yang lebar (7:13), jalan yang sempit dan bukan jalan yang luas $(7: 14)$, menjauhi pengajaran

\footnotetext{
${ }^{42}$ Hannan berkata bahwa ayat ini menyatakan sebuah "mutual reciprocity of the gift of God's saving presence and the disciple's loving response" (The Nature and Demands, 62).

${ }^{43}$ Hagner mengatakan, "The golden rule is properly regarded as an exegesis of the great positive commandment of Lev. 19:18 . . . to 'love your neighbor as yourself' is the equivalent of doing to others what you would have them do to you, and thus the latter can also be described as the essense of 'the law and the prophets"' (Matthew 1-13, 175).
}

nabi-nabi palsu (7:15), menghasilkan buahbuah yang baik dan bukan yang tidak baik (7:19-20), serta membangun rumahnya di atas batu dan bukan di atas pasir (7:24-27). Semua metafora itu menekankan bahwa para murid yang berespons dengan tepat terhadap kehadiran Kerajaan Allah adalah mereka yang telah mempraktikkan kesalehan yang lebih baik dari para pemimpin agama Yahudi, dengan melakukan kehendak Allah Bapa di surga $(7: 21)$.

\section{MISI KERAJAAN ALLAH (8:1-10:42)}

\section{Narasi Misi Kerajaan Allah (8:1-9:38)}

Dalam narasi misi Kerajaan Allah, Matius menunjukkan bahwa Yesus menghadirkan Kerajaan Allah tidak hanya melalui pengajaran-Nya saja tetapi juga melalui perbuatan-perbuatan-Nya yang ajaib. Kerajaan Allah yang dinyatakan oleh Yesus ini sanggup mengendalikan kekacauan alam yang mengancam hidup manusia (8:23-27), serta berkuasa untuk membebaskan dan mengubah kehidupan manusia yang sudah dirusak oleh dosa dan kuasa kegelapan (8:1-17, 28-34; 9:1-13, 18-34). Kehadiran Kerajaan Allah ini juga dinyatakan Yesus secara implisit dalam 9:14-17, yaitu ketika Ia menjawab pertanyaan mengenai hal berpuasa dengan gambaran mengenai diri-Nya sebagai mempelai laki-laki di pesta pernikahan. ${ }^{44}$

Semua perbuatan Yesus yang ajaib itu menggambarkan Kerajaan Allah sebagai belas kasihan dan kemurahan Allah yang mau memanggil, mengampuni dan memulihkan kehidupan orang-orang yang dipandang berdosa, rendah, disisihkan dan bahkan ditolak oleh masyarakat. ${ }^{45}$ Hal ini mengindikasikan

\footnotetext{
${ }^{44}$ Hagner mengatakan, "The announcement of the presence of the messianic kingdom is similar to being present at a great wedding banquet" (Matthew 1-13, 243).

${ }^{45}$ Orang yang sakit kusta dan wanita yang sakit pendarahan adalah orang yang disisihkan dari komunitas karena kondisi fisiknya yang dipandang najis (Im. 13:45-46; 15:1923). Orang-orang sakit dan kerasukan setan dianggap pendosa (bdk. 9:2). Perwira dari Kapernaum dan orang yang kerasukan setan di Gadara adalah orang yang ditolak karena bukan orang Yahudi. Ibu mertua Petrus adalah
} 
dengan jelas bahwa Kerajaan Allah terbuka untuk semua orang tanpa membedakan etnis dan status. Namun demikian, manusia tetap harus memberikan respons terhadap kehadiran Kerajaan Allah tersebut. Yesus memperlihatkan ada dua jenis respons yang kontras-menerima atau menolak-beserta konsekuensinya (8:11-12). Orang-orang Farisi mewakili orang-orang Yahudi yang menolak kehadiran Kerajaan Allah, sementara orangorang yang dipandang rendah dalam masyarakat justru adalah pihak yang menerima kehadiran Kerajaan Allah. ${ }^{46}$

Kehadiran Kerajaan Allah yang penuh kemurahan itu seharusnya direspons dengan sikap percaya dan taat sepenuhnya kepada Yesus yang menghadirkan Kerajaan Allah tersebut (8:8-10; 9:7, 9, 18, 22, 28). Matius juga menyisipkan narasi pemuridan (8:18-27; 9:9-13) untuk menekankan bahwa menjadi murid Yesus tidak cukup hanya ditunjukkan dengan keinginan untuk menemani, mendengarkan, belajar dan hidup bersama dengan-Nya saja sebagaimana yang dilakukan seorang murid rabi. ${ }^{47}$ Mengikut Yesus melibatkan komitmen total di dalam seluruh aspek kehidupan. Itulah sebabnya ketika ada seorang ahli Taurat yang menyatakan ingin mengikut Yesus ke mana saja (8:19), Yesus langsung menghadapkannya dengan tuntutan pemuridan (8:20), yang mengindikasikan adanya harga yang harus dibayar, yaitu kehidupan yang berat dan penuh dengan penyangkalan diri. Seorang murid juga dituntut untuk meninggalkan keterikatan dengan keluarga dan hanya meng-

orang yang dipandang rendah di dalam masyarakat Yahudi karena keberadaannya sebagai seorang wanita yang tidak mempunyai hak suara (Hagner, Matthew 1-13, 207). Lewi pemungut cukai adalah orang yang ditolak masyarakat karena profesinya yang dipandang sebagai antek-antek penjajah (Keener, The Gospel of Matthew, 292-293).

${ }^{46}$ Mengenai 8:11-12, Pennington berkata, "The kingdom is being transferred from the disobedient sons to the followers of Jesus" (Heaven and Earth, 90). Menurut Pennington, anak-anak Kerajaan di ayat 12 merujuk kepada "unbelieving Jews'notion of Jewish-only kingdom" (ibid., 314). Di sini Yesus memperlihatkan kontras antara kerajaan surga yang lebih luas, mencakup orang-orang non-Yahudi maupun kaum marjinal, dengan kerajaan orang Yahudi saja.

${ }^{47}$ Hagner, Matthew 1-13, 216. ikatkan diri dengan Yesus (8:21-22). Matius juga mencatat kisah seorang pemungut cukai (yang kemungkinan adalah dirinya sendiri) sebagai representasi murid sejati (9:9-13). Pemungut cukai ini mengakui otoritas Yesus atas hidupnya, yang ditunjukkannya melalui respons yang diberikannya terhadap panggilan Yesus, yaitu berdiri dan mengikut Dia (9:9). Respons pemungut cukai ini mengindikasikan komitmennya secara total untuk menjadi murid Yesus, yaitu meninggalkan segala sesuatu demi mengikut Dia (bdk. Luk. 5:28).

Narasi pasal 8 dan 9 ini diakhiri dengan sebuah konklusi (9:35-38) yang sekaligus juga merupakan transisi untuk masuk ke khotbah Yesus mengenai misi kerajaan (10:1-42). Pernyataan mengenai belas kasihan Yesus kepada orang banyak serta deskripsi mengenai tuaian yang banyak dan memerlukan pekerja untuk menuainya (9:36-38) mendasari khotbah pengutusan Yesus kepada murid-muridNya, yaitu agar mereka menjadi pekerja bagi tuaian tersebut.

\section{Pengajaran Misi Kerajaan Allah (10:1-42)}

Yesus memanggil dan mengutus para muridNya untuk ikut berpartisipasi dalam misi Kerajaan Allah dan sekaligus juga menjadi solusi bagi kebutuhan pekerja untuk tuaian yang telah diungkapkan dalam bagian sebelumnya (9:36-38). ${ }^{48}$ Para murid menerima mandat untuk melaksanakan misi yang sama seperti misi Yesus, yaitu memberitakan injil Kerajaan Allah dan mendemonstrasikan kuasanya (10:7-8 bdk. 4:17, 23). Gaya hidup Yesus menjadi model bagaimana seharusnya misi itu dijalankan dan bagaimana seharusnya sikap para murid dalam mengerjakan misi tersebut $(10: 5-15){ }^{49}$

\footnotetext{
${ }^{48}$ Terence L. Donaldson mengatakan, "Jesus not only asks his disciples to pray for more worker (9:37), but also sends them out to engage in the same ministry of healing and preaching ... that he himself has been carrying out from the outset . . thereby making them the answer to their own prayers even before they had time to pray" "Guiding Readers-Making Disciples: Discipleship in Matthew's Narrative Strategy" dalam The Pattern of Discipleship in the New Testament, ed. Richard N. Longenecker [Grand Rapids: Eerdmans, 1996], 36).
}

${ }^{49}$ Hannan, The Nature and Demands, 79-80. 
Matius juga memperlihatkan bahwa sejak awal misi Kerajaan Allah telah menghadapi penentangan yang terus-menerus, khususnya dari para pemimpin agama Yahudi. Yesus memberi peringatan tentang kesukaran dan penganiayaan yang akan dihadapi para murid ketika menjalankan misi Kerajaan Allah (10:16-23). Yesus juga memberi nasihat kepada para murid untuk bertekun di dalam tugas panggilan mereka dengan tetap beriman, berani dan setia (10:24-42). Di tengah tantangan yang demikian, para murid diperhadapkan pada pilihan untuk berespons mengakui atau menyangkal Yesus (10:32-33).

Mengakui Yesus di depan umum berarti menerima pribadi-Nya dan berita yang disampaikan-Nya serta mengikut Dia sebagai murid-Nya. Menjadi murid Yesus menuntut komitmen total: penyerahan diri secara mutlak kepada-Nya dan mengikut Dia sepenuhnya sekalipun harus kehilangan nyawa (10:37-39).${ }^{50}$ Namun, pemuridan tidak hanya mencakup aspek vertikal saja (kesetiaan murid kepada Yesus), tetapi juga aspek horizontal, yaitu kesetiaan seorang murid terhadap sesama murid. Ciri seorang murid yang sejati juga mencakup kerelaan untuk mengambil risiko demi menyambut dan menerima sesama murid yang mengalami kesulitan dan penganiayaan (10:41-42), sebab melakukan hal itu sama artinya dengan menerima Yesus sendiri (10:40).

\section{RAHASIA KERAJAAN ALLAH (11:1-13:53)}

\section{Narasi Rahasia Kerajaan Allah (11:1-12:50)}

Matius mengawali narasi rahasia Kerajaan Allah dalam bentuk percakapan Yesus dengan diri-Nya sendiri berupa perenungan mengenai hubungan antara misi-Nya dengan misi Yohanes Pembaptis serta berbagai penolakan dari

${ }^{50}$ France mengatakan bahwa menyambut panggilan menjadi murid Yesus pada hakikatnya berarti menyerahkan hidup, seakan-akan turut serta dalam suatu pawai pemakaman-yaitu pemakaman diri sendiri (R.T. France, Yesus Sang Radikal: Potret Manusia yang Disalibkan, terj. P.G. Katoppo [Jakarta: Gunung Mulia, 2004], 53). orang-orang Yahudi (11:2-30). ${ }^{51}$ Yesus memperlihatkan signifikansi pribadi dan pelayanan Yohanes Pembaptis sebagai pembuka jalan bagi kedatangan dan penggenapan Kerajaan Allah. Namun, yang terkecil dalam Kerajaan Allah, yaitu yang berespons terhadap proklamasi injil Yesus dan bertobat, lebih besar dari Yohanes, karena memiliki kedudukan yang terhormat dalam Kerajaan Allah (11:215). Yesus juga memberi peringatan keras kepada mereka yang telah melihat Kerajaan Allah dimanifestasikan dan didemonstrasikan oleh pelayanan-Nya, namun tidak berespons dengan seharusnya: bertobat dan menerima pengajaran-Nya (11:16-24).

Namun demikian, kesempatan untuk menjadi murid Yesus tetap terbuka. Hanya saja, yang dapat menjadi murid Yesus bukanlah mereka yang bangga dengan kepandaiannya dan puas dengan dirinya sendiri sehingga tidak mau menerima ajaran, melainkan mereka yang bersikap seperti anak kecil: terbuka, mau diajar dan menerima Kerajaan Allah (11:2527 bdk. 18:1-4). Dalam konteks inilah Yesus mengundang semua yang letih lesu dan berbeban berat untuk datang kepada-Nya, yaitu untuk mengikut Dia dan memikul kuk yang diberikan-Nya (11:28-30). ${ }^{52}$ Undangan ini adalah sebuah panggilan untuk tunduk dan taat melakukan kehendak Allah yang dinyatakan Yesus dalam pengajaran-Nya. ${ }^{53}$

\footnotetext{
${ }^{51}$ Hannan, The Nature and Demands, 84.
}

${ }^{52}$ Mereka yang letih lesu dan berbeban berat adalah mereka yang dibebani dengan usaha untuk taat kepada hukum Taurat dengan harapan dapat memperoleh kebenaran. Sebenarnya yang membebani mereka bukanlah hukum Taurat itu sendiri melainkan penafsiran para pemimpin agama Yahudi terhadap Taurat yang dijadikan sebagai hukum yang harus ditaati. Hagner mengatakan, "The Pharisees spoke of 613 commandments and their hălākôt ('rulings') involved a complicated casuistry" (Matthew 1-13, 323). Kepada mereka yang berbeban berat inilah Yesus memberikan panggilan untuk datang kepada-Nya. Undangan untuk datang kepada Yesus ini adalah undangan pemuridan, yaitu untuk mengikut Dia dan ajaran-Nya. Yesus menjanjikan kelegaan kepada mereka yang datang kepada-Nya karena kuk yang Yesus berikan enak dan beban-Nya pun ringan (11:30).

\footnotetext{
${ }^{53} \mathrm{Kuk}$ adalah sebuah simbol ketundukan kepada aturan atau otoritas (Keener, The Gospel of Matthew, 348). Kuk yang dimaksud Yesus adalah ajaran-ajaran-Nya, dan interpretasinya terhadap Taurat yang berbeda dengan
} 
Dalam narasi ini, Matius juga memperlihatkan bahwa orang-orang Farisi adalah pihak yang dengan jelas memberikan respons negatif terhadap pelayanan Yesus. Hal ini diungkapkan Matius melalui tiga hal: pertama, rencana mereka untuk membunuh Yesus (12:14); kedua, pernyataan mereka yang menyamakan kuasa Yesus dengan Beelzebul (12:22-24); dan ketiga, permintaan mereka untuk melihat tanda dari Yesus (12:38-42). Ketiga hal ini membuktikan bahwa orang-orang Farisi ini adalah orang-orang yang terang-terangan menolak pribadi dan pelayanan Yesus, yang menghadirkan Kerajaan Allah. Dengan menolak Yesus, mereka telah menolak Kerajaan Allah. Yesus menyebut mereka sebagai angkatan yang jahat dan tidak setia (12:39). Angkatan yang menolak kehadiran Kerajaan Allah dan berakhir dengan kehancuran ini (12:45) dikontraskan dengan komunitas pengikut Yesus yang sejati, yaitu mereka yang taat melakukan kehendak Allah Bapa di surga (12:48-50). Inilah ciri-ciri seorang murid sejati yang ditekankan oleh Yesus, bukan hanya sekadar mendengar atau menyetujui pengajaran Yesus melainkan yang berespons dengan komitmen untuk taat kepada kehendak Allah.

\section{Pengajaran Rahasia Kerajaan Allah (13:1-53)}

Matius melanjutkan narasinya dengan pengajaran Yesus secara khusus kepada para murid-Nya, yaitu rahasia Kerajaan Allah $^{54}$ yang disampaikan-Nya dalam bentuk perumpamaan-perumpamaan beserta maknanya. Meskipun perumpamaan-perumpamaan ini mengenai Kerajaan Allah, tema utama yang mendapat penekanan adalah respons orang-

penafsiran orang-orang Farisi. Dengan demikian, ketika Yesus berkata "pikullah kuk yang Kupasang," hal ini berarti sebuah undangan untuk mengikuti ajaran-Nya sebagai interpretasi yang tepat terhadap Taurat (Hagner, Matthew, 324).

${ }^{54}$ Frasa "rahasia Kerajaan Allah" menunjuk kepada seluruh pengajaran Yesus sebagai wahyu ilahi yang menyingkapkan kebenaran mengenai kehadiran Kerajaan Allah dan bagaimana seharusnya para murid berespons dengan hidup di bawah pemerintahan Allah (Hannan, The Nature and Demands, 105). orang terhadap Kerajaan Allah tersebut. ${ }^{55}$ Perumpamaan yang Yesus ajarkan ini dapat dikatakan memiliki fungsi rangkap dua, yaitu memisahkan antara mereka yang menerima berita Kerajaan Allah dan yang menolaknya.

Dalam perumpamaan tentang seorang penabur, Yesus mengungkapkan bahwa respons yang tepat terhadap berita Kerajaan Allah yang Yesus wartakan adalah mendengar dan mengerti (13:23). "Mengerti" merupakan kata yang menentukan, karena menyatakan kesediaan menerima berita Kerajaan Allah tersebut. Di akhir rangkaian perumpamaan yang disampaikan-Nya, Yesus bertanya kepada para murid: "Mengertikah kamu semuanya itu?" (13:51). Jawaban para murid menunjukkan perbedaan antara mereka dengan orang banyak, yang sekalipun diajar namun tidak mengerti. Respons inilah yang memungkinkan seseorang memahami rahasia Kerajaan Allah yang Yesus ungkapkan melalui berbagai perumpamaan. Tanpa kesediaan untuk menerima berita Kerajaan Allah yang Yesus wartakan, tidak mungkin seseorang dapat memahami perumpamaan-perumpamaan Yesus. Hal ini Yesus ungkapkan dalam jawaban-Nya kepara para murid yang mempertanyakan alasan Yesus berkata-kata dalam perumpamaan (13:10). Dalam jawaban-Nya tersebut, Yesus menyatakan bahwa hanya orang yang menyambut berita Kerajaan Allah dan berkomitmen mengikut Dia (diungkapkan dengan frasa "siapa yang mempunyai" di 13:12) yang dapat memahami rahasia Kerajaan Allah tersebut.

Kepada para murid-Nya, Yesus juga secara khusus mengungkapkan dua perumpamaan lainnya, yaitu perumpamaan tentang harta terpendam (13:44) dan mutiara berharga (13:45). Kedua perumpamaan ini berbicara mengenai masalah pemuridan, yaitu melepaskan keterikatan dengan segala sesuatu demi mengikut Yesus. Ia mengungkapkan

\footnotetext{
${ }^{55}$ France mengatakan bahwa perumpamaan-perumpamaan ini "are often referred to as 'parables of the kingdom,'. . . but it is men's response to the preaching of God's kingdom which is their theme, and in this response there is a division between fruitful soil and unproductive, good grain and weeds, good fish and bad" (Matthew, 216).
} 
hal ini melalui pertama, sikap seorang yang menjual seluruh miliknya demi memperoleh harta yang terpendam; dan kedua, sikap seorang pedagang yang juga menjual seluruh miliknya untuk memperoleh mutiara yang indah. Melalui dua perumpamaan ini para murid diingatkan kembali akan panggilan pemuridan yang Yesus berikan kepada mereka $(8: 18-22 ; 10: 37-39)$.

Di samping para murid yang menerima berita Kerajaan Allah, ada pula orang-orang yang mengeraskan hati dengan menolak berita Kerajaan Allah yang Yesus wartakan. Mereka inilah yang dinyatakan dengan frasa "siapa yang tidak mempunyai" (13:12). Dalam perumpamaan Yesus, orang-orang ini diumpamakan seperti lalang di antara gandum (13:24-30), dan disebut "anak-anak si jahat" (13:38) atau "orang jahat" (13:49-50). Mereka adalah contoh nyata dari orang-orang yang tidak berespons, seperti yang Yesus katakan: "sekalipun melihat, mereka tidak melihat dan sekalipun mendengar, mereka tidak mendengar dan tidak mengerti" (13:13-15). Respons penolakan inilah yang akan menjadi dasar penghukuman yang akan dilaksanakan pada waktu menuai-akhir zaman (13:40-42, 49-50).

Jadi, pemisahan antara anggota Kerajaan Allah dengan yang bukan ditentukan berdasarkan kriteria "mendengar dan mengerti." Anggota Kerajaan Allah adalah para murid yang mau mendengar dan menerima pengajaran Yesus serta dimampukan untuk mengerti pengajaran itu. Para murid yang telah memiliki pengenalan yang sejati akan pengajaran Yesus, kelak akan menceritakan kembali perumpamaan-perumpamaan ini (dan juga pengajaran Yesus lainnya) kepada generasi murid selanjutnya (13:52). Matius sendiri adalah contoh dari murid yang demikian. ${ }^{56}$

${ }^{56}$ Hannan berkata, "Matthew, thus, models what it means to be a scribe trained for the Kingdom of Heavens. By retelling the parables of Jesus, he does what Jesus does. . . He thereby encourages all future disciples of Jesus to keep his teaching on the Kingdom of Heavens alive and fruitful" (The Nature and Demands, 121).

\section{KELUARGA KERAJAAN ALLAH (13:54-18:35) \\ Narasi Keluarga Kerajaan Allah \\ (13:54-17:27)}

Matius melanjutkan narasinya dengan berfokus pada bagaimana Yesus membangun komunitas Kerajaan Allah di atas dasar wahyu Allah kepada Petrus yang menyingkapkan identitas Yesus sebagai Mesias. Di dalam pembahasan mengenai identitas Yesus ini, Matius memperlihatkan pemahaman orang-orang mengenai siapa Yesus dengan puncaknya adalah pada percakapan Yesus dengan murid-muridNya mengenai siapa diri-Nya (16:13-20). Jawaban para murid terhadap pertanyaan ini mengindikasikan ada berbagai opini terhadap siapa Yesus sesungguhnya. Catatan Matius mengenai Herodes (14:1-2) juga merupakan salah satu contoh opini tersebut. Identitas Yesus yang sesungguhnya ditunjukkan Matius melalui jawaban Petrus (16:16): "Engkau adalah Mesias, Anak Allah yang hidup!” Pernyataan yang sama juga diungkapkan perempuan Kanaan yang memohon supaya Yesus menyembuhkan anaknya (15:21-28, bdk. 9:27; 20:30-31): "Kasihanilah aku, ya Tuhan, Anak Daud." ${ }^{57}$ Matius meneguhkan identitas Yesus sebagai Mesias ini dengan mencatat berbagai mukjizat yang Yesus lakukan (14:13-36; 15:29-39), dan juga melalui peristiwa transfigurasi Yesus (17:1-13). Matius juga ingin memperlihatkan bahwa Petrus (mewakili para murid) dan perempuan Kanaan (mewakili bangsa non-Yahudi) adalah orang-orang yang mengenali identitas Yesus sesungguhnya. Mereka adalah orang-orang yang membuka hatinya terhadap berita Kerajaan Allah yang Yesus wartakan (bdk. 13:16). Sementara

${ }^{57}$ Gelar "Anak Daud" adalah gelar yang ditujukan untuk Mesias. Dengan demikian, ketika perempuan Kanaan tersebut menyebut Yesus sebagai Anak Daud, secara tidak langsung ia menyatakan dan mengakui otoritas Yesus sebagai Mesias. Yesus mendapati bahwa perempuan Kanaan tersebut memiliki iman yang besar, dan karena itulah permohonannya dikabulkan Yesus (15:28; bdk. 8:10). Kisah perempuan Kanaan ini mengindikasikan dengan jelas bahwa sekalipun pelayanan Yesus ditujukan secara khusus untuk domba-domba yang hilang dari umat Israel (bdk. 10:5-6), bangsa bukan Yahudi pun tetap menjadi bagian dari pelayanan-Nya. 
itu, orang-orang Farisi, Saduki serta ahli-ahli Taurat adalah orang-orang yang mengeraskan hati dan tidak mau menerima berita Kerajaan Allah yang Yesus wartakan (15:1-11; 16:1-4, bdk. 12:38-42).

Matius juga mengungkapkan bahwa adakalanya para murid gagal untuk percaya sepenuhnya kepada Yesus. Para murid gagal mengimani Yesus akan mencukupkan kebutuhan makanan bagi orang banyak (14:13-21; 15:3239). Para murid tidak mengenali Yesus yang berjalan di atas air (14:22-27). Petrus kurang percaya kepada Yesus (14:28-33). Para murid (diwakili Petrus) tidak memahami pengajaran yang Yesus sampaikan (15:12-20; 16:5-11; 16:22-23). Para murid juga kurang percaya pada kuasa Yesus yang diberikan kepada mereka (17:19-20). Namun demikian, Yesus tetap menyatakan diri dan memberikan panggilan pemuridan kepada mereka (16:21-28), sebab pada dasarnya para murid ini memiliki hati yang responsif terhadap Kerajaan Allah. Respons positif inilah yang memungkinkan para murid mengerti $(16: 12 ; 17: 13)$ apa yang Yesus ajarkan kepada mereka walaupun awalnya mereka tidak mengerti (bdk. 15:15-16; 16:22-23). ${ }^{58} \mathrm{Hal}$ inilah yang membedakan para murid dengan para pemimpin agama Yahudi. Murid yang sejati adalah orang yang berespons positif dan membuka hati bagi kehadiran Yesus, Sang Mesias yang menghadirkan Kerajaan Allah, percaya penuh kepada-Nya, mau terus diajar dan belajar dari-Nya.

\section{Pengajaran Keluarga Kerajaan Allah} (18:1-35)

Di bagian sebelumnya, Matius telah menguraikan bahwa Yesus membentuk komunitas keluarga Kerajaan Allah di atas dasar pengakuan Petrus bahwa diri-Nya adalah Mesias, Anak Allah yang hidup. Sekarang di bagian ini Matius berbicara mengenai gaya hidup komunitas Kerajaan Allah yang dicirikan

\footnotetext{
${ }^{58}$ Pernyataan bahwa murid-murid mengerti apa yang Yesus katakan ini tampaknya merupakan tambahan Matius terhadap catatan Markus (bdk. Mrk. 8:14-21; 9:2-13). Hal ini membuktikan bahwa istilah "mengerti" merupakan istilah yang penting dalam Injil Matius ini dan sekaligus juga menjadi kriteria yang membedakan antara anggota komunitas Kerajaan Allah dengan yang bukan.
}

dengan empat gaya hidup. Pertama, keluarga Kerajaan Allah hidup dalam kerendahan hati (18:1-4). ${ }^{59}$ Yesus mengungkapkan bahwa yang terbesar dalam Kerajaan Allah adalah mereka yang merendahkan diri dan menjadi seperti anak kecil (18:4). Melalui hal ini, Yesus menunjukkan bahwa gaya hidup komunitas Kerajaan Allah bukanlah mengejar status dan kekuasaan sebagaimana yang dunia lakukan, melainkan dengan rendah hati bergantung penuh kepada Allah Bapa di surga. Kedua, keluarga Kerajaan Allah menerima/menyambut sesama saudara, dan bukan menyesatkannya (18:5-9). ${ }^{60}$ Ketiga, keluarga Kerajaan Allah peduli terhadap sesama saudara yang tersesat/terhilang (18:10-12). Dengan menggunakan perumpamaan domba yang hilang, Matius menegaskan bahwa mencari dan menyelamatkan sesama saudara yang tersesat/terhilang adalah tanggung jawab seluruh komunitas, karena mereka berharga dan Bapa di surga tidak menghendaki ada satu pun yang hilang. Hal ini dapat dilakukan dengan langkah-langkah yang diungkapkan dalam 18:15-20. Keempat, keluarga Kerajaan Allah sedia mengampuni sesama saudara yang bersalah sama seperti Allah telah lebih dahulu mengampuni mereka (18:21-35).

\section{MASA DEPAN KERAJAAN ALLAH} (19:1-25:46)

\section{Narasi Masa Depan Kerajaan Allah (19:1-23:39)}

Bagian ini menandai awal perjalanan Yesus dari Yudea menuju Yerusalem, yang

\footnotetext{
${ }^{59}$ Craig S. Keener mengatakan, "In Jewish culture, children . . . had no status . . and no power or privileges apart from what they received as total dependents on their parents" (The IVP Bible Background Commentary: New Testament [Downers Grove: InterVarsity, 1993], 93).

${ }^{60}$ Penerimaan yang dimaksud di sini mengacu kepada pemberian tumpangan kepada murid lainnya, yang mungkin sedang dalam perjalanan (Donald A. Hagner, Matthew 14-28, Word Biblical Commentary 33b [Dallas: Word, 1993], 522). Sikap "penerimaan" ini dikontraskan Yesus dengan sikap yang menyesatkan, dalam arti menyebabkan seseorang tersandung atau jatuh dalam dosa atau bahkan kehilangan iman. Bagi Yesus, seorang penyesat lebih baik ditenggelamkan ke dalam laut daripada ia menyesatkan orang lain. Hal ini menunjukkan betapa seriusnya akibat yang harus ditanggung oleh seorang yang menyesatkan sesamanya.
} 
merupakan klimaks dari misinya (19:1). Sepanjang perjalanan-Nya menuju Yerusalem, Yesus banyak memberikan pengajaran kepada murid-murid-Nya. Menjawab pertanyaan yang diajukan oleh orang-orang Farisi kepada-Nya mengenai perceraian, Yesus mengungkapkan kepada para murid-Nya bahwa kehadiran Kerajaan Allah menuntut adanya kesempurnaan sebagaimana dunia ini pada mulanya diciptakan (19:2-6). ${ }^{61}$ Oleh karena itu, etika dan cara pandang yang berlaku dalam Kerajaan Allah tidak sama dengan etika dan cara pandang yang berlaku di dunia ini. ${ }^{62}$ Perbedaan perspektif ini terlihat lebih jelas di dalam kisah seorang muda yang kaya.

Matius mencatat kisah mengenai seorang muda yang menawarkan dirinya untuk mengikut Yesus, namun ketika dihadapkan dengan tuntutan pemuridan, orang muda ini menolaknya (19:16-22). Kunci untuk memahami makna kisah ini terletak pada frasa "Jikalau engkau hendak sempurna" (21) yang Matius tambahkan dan tidak ada di Injil Markus maupun Injil Lukas. Kata "sempurna" menggaungkan kembali khotbah Yesus di bukit (5:48). ${ }^{63}$ Secara umum, kata "sempurna" ini dimengerti dalam pemahaman tradisi Yahudi sebagai komitmen yang tidak terbagi kepada Allah. ${ }^{64}$ Namun demikian, jika melihat kon-

\footnotetext{
${ }^{61} \mathrm{Hal}$ ini dapat dilihat dari jawaban Yesus terhadap pertanyaan orang-orang Farisi tersebut, yang mengacu kepada penciptaan manusia (19:4-5). Hagner mengatakan, "The genesis account describes the will of God (cf. Mal. 2:16), indeed, the original will of God as established in the account of creation itself" (Matthew 14-28, 548). Dalam bagian lain, Hagner juga mengatakan bahwa jawaban Yesus kepada orang-orang Farisi ini memiliki implikasi bahwa "the new era of the present kingdom of God involves a return to the idealism of the prefall Genesis narative. The call of the kingdom is a call to the ethics of the perfect will of God" (ibid., 549).

${ }^{62}$ Sebagai contoh, dalam budaya Yahudi anak-anak tidak memiliki tempat yang khusus (ibid., 553), namun bagi Yesus, anak-anak itu berharga dan memiliki tempat khusus dalam Kerajaan Allah. Itulah sebabnya, Ia menyediakan waktu untuk melayani dan memberkati anak-anak tersebut (19:13-15).

${ }^{63} \mathrm{Di}$ sini Matius menggunakan kata Yunani yang sama: $\tau \varepsilon \dot{\lambda} \varepsilon 10 \varsigma$.

${ }^{64}$ Hagner mengatakan, "Discipleship is a matter of total, undistracted, and unqualified commitment" (Matthew 14-28, $562)$.
}

teks ayat ini, Yesus mau menyatakan kesempurnaan yang dituntut Kerajaan Allah memiliki nuansa yang lebih dari hal di atas. Kata "sempurna" di ayat ini maupun di pasal 5:48 dikelilingi oleh pesan Yesus untuk mengasihi sesama. ${ }^{65}$ Selain itu, makna yang paling penting berkaitan dengan kesempurnaan di sini adalah mengikut Yesus ("datanglah ke mari dan ikutlah Aku"). ${ }^{66}$ Jadi, dapat disimpulkan bahwa kesempurnaan yang dituntut oleh Kerajaan Allah adalah ketaatan radikal kepada Allah yang diwujudkan dengan komitmen total mengikut Yesus dan mengasihi sesama. Bagi Matius, kesempurnaan ini bukanlah tahap tertinggi dalam kehidupan Kristen dan juga bukan diperuntukkan hanya kepada beberapa murid saja yang dipanggil secara khusus, melainkan adalah panggilan kepada semua orang percaya.

Dalam perjalanan ini, Yesus juga secara khusus memberitahukan kepada para murid mengenai penderitaan dan kematian yang akan dialami-Nya di Yerusalem (20:17-19). Namun demikian, murid-murid tampaknya tidak memahami nubuat Yesus ini. Mereka malah memperebutkan posisi terbesar dalam Kerajaan Allah (20:21). Melalui peristiwa ini, Yesus mengajar murid-murid-Nya bahwa posisi terbesar di dalam Kerajaan Allah diperoleh hanya dengan cara melayani (20:26-27), dan Ia menunjukkan bahwa diri-Nya adalah contoh dalam hal ini. Meskipun sebagai Anak Manusia, Yesus adalah Mesias dan wakil Allah yang memiliki kedudukan tinggi di hari penghakiman $(10: 32 ; 13: 41 ; 16: 27$ 28), Ia datang untuk melayani dan memberikan nyawa-Nya menjadi tebusan bagi banyak orang (20:28). Ia menggenapi alusi hamba TUHAN dari Yesaya 53 sebagai teladan hamba yang merendahkan diri-Nya hingga mengorbankan nyawa-Nya demi menaati kehendak Allah dan mengasihi orang-orang

\footnotetext{
${ }^{65}$ Ulrich Luz, Matthew 8-20: A Commentary (Augsburg: Fortress, 2001), 513.

${ }^{66} \mathrm{Luz}$ berkata, "perfection is a matter of following Jesus" (ibid., 514).
} 
yang Allah percayakan kepada-Nya. ${ }^{67}$ Kingsbury melihat teladan penghambaan Yesus ini sebagai "essence of discipleship" yang juga dituntut Yesus dari para murid-Nya. ${ }^{68}$

Setibanya di Yerusalem, Yesus memasuki kota itu dengan mengendarai seekor keledai (21:14), yang merupakan penggenapan dari nubuat Zakharia (Za. 9:9-10). Kedatangan Yesus ke Yerusalem ini disambut orang banyak dengan memberikan penghormatan sebagaimana layaknya diberikan kepada seorang raja (21:7-9, bdk. 2Raj. 9:13). Dengan demikian, peristiwa ini (21:1-11) menunjukkan dengan jelas identitas Yesus sebagai Raja Mesias yang kehadiran-Nya telah dinubuatkan oleh nabinabi Perjanjian Lama. Identitas Yesus sebagai Mesias juga diperlihatkan-Nya melalui tindakan-tindakan-Nya. Ia mengusir orang yang berjual beli di halaman Bait Allah ${ }^{69}$ (21:12-13) sebagai penggenapan dari Yesaya 56:7 dan Yeremia 7:8-11 untuk memulihkan ibadah yang sepatutnya bagi pemerintahan Allah yang sudah hadir. Ia juga menyembuhkan orang-orang buta dan timpang di dalam Bait Allah (21:14) untuk menggenapi nubuat Mikha 4:6-7 yang menandakan TUHAN hadir sebagai raja di Sion serta merangkul orang-orang yang ditolak oleh tatanan dunia

\footnotetext{
${ }^{67}$ Hannan, The Nature and Demands, 168. Ben Cooper dalam disertasinya yang berfokus pada Injil Matius juga menyorot pribadi dan tindakan Yesus sebagai teladan hamba TUHAN yang digambarkan oleh Yesaya (Incorporated Servanthood: Commitment and Discipleship in the Gospel of Matthew, Library of New Testament Studies 490 [New York: Bloomsbury, 2013], 10, 84, 165). Karena itu, dalam hal ini penulis kontra dengan pandangan Luz mengenai ayat ini yang mengatakan, "Matthew will hardly have been thinking here of an individual biblical text, certainly not of Isa 53:10-12, a text that has scarcely any common vocabulary with Matthew and that also has no particular meaning elsewhere for Matthew" (Matthew 8-20, 546).

${ }^{68}$ Kingsbury, Matthew as Story, 144.

${ }^{69}$ Tindakan Yesus ini menyingkapkan bahwa Bait Allah sesungguhnya sudah tidak berfungsi sebagaimana seharusnya. Hal ini digambarkan Yesus melalui perumpamaan pohon ara yang tidak berbuah (21:19). France mengatakan bahwa tindakan Yesus mengutuk pohon ara merupakan sebuah tindakan simbolik: "a tree which promises fruit but provides none is an apt symbol of a religion without godliness, and the summary destruction of the tree can only point in the same direction as Jesus' demonstration in the temple" (Matthew, 303).
}

ini. $^{70}$ Melalui tindakan-tindakan-Nya ini, Yesus mau menunjukkan bahwa pemerintahan Allah yang selama ini dilambangkan oleh Bait Allah, sekarang sudah hadir secara nyata di dalam diri dan pelayanan-Nya. Tindakan-tindakan Yesus di atas memicu pertentangan dari para imam kepala dan ahli-ahli Taurat yang mempertanyakan otoritas Yesus $(21: 23) \cdot{ }^{71}$

Yesus menjawab pertanyaan mereka melalui tiga perumpamaan. Melalui perumpamaan dua orang anak (21:28-32) dan perumpamaan perjamuan kawin (22:1-14) Yesus mengajarkan bahwa respons yang seharusnya terhadap undangan Kerajaan Allah adalah kerelaan untuk menerima dan tunduk di bawah kerajaan Allah dengan sikap bertobat dan hidup menurut jalan kebenaran yang telah ditunjukkan oleh Yohanes Pembaptis (21:32) dan berdasarkan pengajaran Yesus sendiri. ${ }^{72}$ Selain itu, melalui perumpamaan tentang penggarap-penggarap kebun anggur (21:33-36) Yesus melontarkan peringatan keras kepada para pemimpin agama Yahudi saat itu yang menolak diri-Nya, bahwa otoritas kepemimpinan akan diambil dari mereka dan diberikan kepada para pengikut Yesus yang sejati yang telah menghasilkan buah bagi Kerajaan Allah (21:43). Masa depan Kerajaan Allah tidak lagi diidentikkan secara etnis (Israel atau Yahudi) melainkan berdasarkan iman dan kesetiaan kepada Yesus, Sang Batu Penjuru yang datang dari pihak Allah sendiri untuk menegakkan kerajaan-Nya di bumi ini (21:42). Ketiga perumpamaan tersebut mengakibatkan konfrontasi antara para pemimpin

\footnotetext{
${ }^{70}$ Hannan, The Nature and Demands, 171. Tindakan Yesus ini dapat dikatakan juga telah membatalkan ketentuan yang berlaku pada zaman itu, yaitu bahwa orangorang buta dan timpang dilarang memasuki Bait Allah (bdk. Im. 21:18; 2Sam. 5:8).

${ }^{71}$ Bait Allah pada masa itu selain berfungsi sebagai pusat keagamaan orang Yahudi, juga merupakan pusat pemerintahan domestik daerah Yudea dan sekitarnya. Di tempat inilah Sanhedrin yang dipimpin oleh imam besar "berkantor" dan menjalankan pemerintahan. Dengan demikian, tindakan serta pernyataan Yesus (21:12-13) menunjukkan serangan-Nya secara langsung terhadap Sanhedrin (bdk. Kingsbury, Matthew as Story 82).
}

${ }^{72}$ Hannan, The Nature and Demands, 183. 
agama Yahudi dengan Yesus menjadi semakin tajam (21:45-46, bdk. 22:15, 35).

Matius melanjutkan narasinya dengan mencatat kontroversi antara Yesus dengan para pemimpin agama Yahudi yang diwakili oleh orang-orang Farisi, ahli-ahli Taurat dan orang Saduki yang ingin menjerat Yesus (21:46; 22:15, 35). Seluruh percakapan kontroversi ini (22:15-23:36) ingin memperlihatkan bahwa Yesus adalah Sang Mesias representasi Kerajaan Allah yang berotoritas mengembalikan pemahaman yang benar terhadap hukum Taurat sehingga warga Kerajaan Allah dapat hidup menaati kehendak Allah sebagai fondasi dari kehidupan yang menghasilkan buah kebenaran dan kesalehan sejati. ${ }^{73}$ Ciri-ciri kehidupan warga Kerajaan Allah yang sejati itu ditandai dengan mengasihi Allah dengan segenap hati, jiwa dan akal budi, serta mengasihi sesama seperti dirinya sendiri (22:37-39). Bagian ini diakhiri Matius dengan mencatat ratapan Yesus terhadap Yerusalem (23:3739), yang menunjukkan belas kasihan Yesus juga kepada para pemimpin agama Yahudi yang tidak percaya dan menolak diri-Nya. Hal ini menunjukkan bahwa undangan Kerajaan Allah tetap terbuka bagi mereka jika mereka mau menerima Yesus dan bertobat. Ratapan Yesus ini sekaligus juga menjadi peringatan dan pengantar ke bagian percakapan selanjutnya dengan para murid yang menyingkapkan berakhirnya kerajaan orang Yahudi sehingga di masa yang akan datang Kerajaan Allah tidak lagi diidentifikasi secara etnis melainkan melalui iman dan ketaatan kepada Yesus.

\section{Pengajaran Masa Depan Kerajaan Allah (24:1-25:46)}

Bagian ini merupakan pengajaran Yesus yang terakhir kepada para murid-Nya sebelum Ia ditangkap. Ada empat hal yang menjadi pokok pengajaran Yesus dalam bagian ini: pertama, peringatan kepada para murid agar waspada terhadap bahaya penyesatan $(24: 4,11)$ : akan ada banyak orang yang mengaku diri sebagai Mesias (24:5, 23-24). Kedua, agar para murid

${ }^{73}$ Ibid., 192. tidak percaya kepada mesias-mesias palsu tersebut (24:25-26). Ketiga, ada penderitaan yang akan dialami oleh para murid (24:9-10, 15-22). Keempat, ada nasihat untuk berjaga-jaga, bertahan sampai pada kesudahannya dengan tetap setia memberitakan injil Kerajaan Allah kepada semua bangsa (24:13-14, 32-36, 43-44) karena Yesus berjanji akan datang kembali dengan segala kekuasaan dan kemuliaan-Nya (24:29-31; 37-42) untuk menghakimi seluruh umat manusia (25:31-46).

Nasihat untuk berjaga-jaga ini dijabarkan Yesus dalam tiga perumpamaan: hamba yang setia dan hamba yang jahat (24:45-51); gadisgadis yang bijaksana dan gadis-gadis yang bodoh (25:1-13); serta talenta (25:14-30). Ketiga perumpamaan ini berbicara mengenai pentingnya seorang pengikut Yesus-digambarkan dengan hamba yang setia; gadis-gadis yang bijaksana; serta hamba yang menerima lima dan dua talenta-untuk tetap hidup sesuai dengan status mereka: setia, taat dan penuh tanggung jawab mengerjakan tugas yang dipercayakan kepada mereka.

Matius menutup bagian ini dengan pengajaran Yesus mengenai penghakiman terakhir yang akan berlangsung pada saat Yesus datang kembali dalam kemuliaan-Nya (25:3146). Penghakiman terakhir ini akan memisahkan antara "domba," yaitu orang-orang yang melakukan perbuatan baik kepada sesamanya (25:35-40), dari "kambing," yaitu orang-orang yang tidak melakukan perbuatan baik kepada sesamanya (25:41-45). ${ }^{74}$ Dengan demikian, jelaslah bahwa karakteristik yang membedakan para murid Kerajaan Allah dari yang bukan adalah perbuatan baik kepada sesama sebagai bentuk ketaatan kepada kehendak Allah. Dalam penghakiman terakhir ini pula akan ada upah yang diberikan kepada masing-masing orang berdasarkan perbuatan

\footnotetext{
${ }^{74}$ Secara tidak langsung, Matius menunjukkan bahwa kriteria pemisahan "domba" dari "kambing" ini adalah berdasarkan pada hukum kasih (Mat. 22:37-39). Peter F. Ellis berkata, "The parable concentrates on only one pointthe criterion according to which the good are judged blessed and the wicked accursed . . is the love commandment" (Matthew: His Mind and His Message [Collegeville: The Liturgical, 1974], 94).
} 
mereka (bdk. 16:27): mereka yang telah berbuat baik akan masuk ke dalam Kerajaan Allah (25:34), sementara mereka yang tidak berbuat baik akan dihukum di dalam api yang kekal (25:41).

Seluruh pengajaran Yesus tentang akhir zaman ini memperingatkan para murid untuk tetap bertekun dalam panggilan mereka sebagai pengikut Yesus selama menantikan kedatangan Yesus kembali. Ketekunan kepada panggilan ini harus diwujudkan dengan sikap yang setia dan taat kepada tugas pemberitaan injil serta perbuatan baik kepada sesama. Mereka inilah yang akan masuk dan menikmati kebahagiaan di dalam Kerajaan Allah $(25: 10,23,34)$.

\section{PENUTUP: KEMATIAN DAN KEBANGKITAN YESUS (26:1-28:20)}

Bagian ini merupakan klimaks Injil Matius di mana seluruh maksud dan tujuan Yesus datang ke dunia ini tergenapi. Di satu sisi narasi ini memperlihatkan bahwa Yesus secara sadar menyerahkan diri-Nya sebagai kurban dalam rangka melaksanakan kehendak Allah (26:12, 39, 42, bdk. 20:17-19; 17:22-23; 16:21). Namun di sisi lain, bagian ini memperlihatkan bahwa para pemimpin agama Yahudi, Yudas dan juga orang banyak bertanggung jawab atas tindakan mereka yang dengan sengaja merencanakan pembunuhan terhadap Yesus. Narasi ini dapat dikatakan sebagai puncak dari penolakan bangsa Yahudi terhadap Yesus. ${ }^{75}$ Matius menunjukkan hal ini melalui pertama, rencana para pemimpin agama Yahudi untuk menangkap dan membunuh Yesus (26:3-5); kedua, permintaan orang banyak agar Yesus disalibkan dan kesediaan mereka untuk bertanggung jawab atas eksekusi tersebut (27:2225); dan ketiga, pengkhianatan salah satu dari dua belas murid-Nya (26:14-16). Namun demikian, Matius menunjukkan bahwa Yesus mengetahui semuanya itu (26:1-2).

${ }^{75}$ Joel B. Green, "Death of Jesus," dalam Dictionary of Jesus and The Gospels, ed. Joel B. Green, Scott McKnight, dan I. Howard Marshall (Downers Grove: InterVarsity, 1992), 154.
Yesus mengetahui bahwa Ia harus menderita dan mati di kayu salib demi mengemban tugas yang Bapa berikan kepada-Nya (26:39, 42). Berulang kali Yesus mengungkapkan mengenai kematian-Nya kepada para muridNya: persiapan untuk penguburan-Nya sudah dilakukan (26:12); waktu-Nya sudah hampir tiba (26:18); pengkhianatan terhadap diriNya yang akan dilakukan oleh salah seorang dari kedua belas murid-Nya $(26: 21,25,50)$. Namun demikian, Yesus juga menyatakan bahwa Ia dapat melepaskan diri-Nya dari penderitaan dan kematian yang akan dialamiNya (26:53). Bahkan, di hadapan Mahkamah Agama Yahudi, Yesus menyatakan diri-Nya sebagai figur Anak Manusia dari Daniel 7:13 dan mesias rajani dari Mazmur 110:1, yaitu posisi-Nya yang tinggi dan dimuliakan Allah serta peran-Nya sebagai representasi Allah yang berdaulat atas seluruh ciptaan dan segala bangsa. ${ }^{76}$ Semua ini menunjukkan bahwa Ia memiliki kuasa dan kendali atas seluruh peristiwa yang akan dialami-Nya. Namun, Ia tidak menggunakan kekuasaan-Nya tersebut untuk melepaskan diri dari penderitaan dan kematian, sebaliknya Ia taat sepenuhnya kepada Allah dan memberikan hidup-Nya untuk semua manusia. ${ }^{77}$

Matius memperlihatkan bahwa para murid yang telah mengikuti Yesus selama kira-kira tiga tahun ini ternyata belum memahami misi Yesus di bumi ini. Mereka gagal memahami Yesus sebagai Mesias yang harus menderita dalam menjalankan misi-Nya $(26: 6-13)^{78}$

\footnotetext{
${ }^{76}$ Craig A. Evans, Jesus and His Contemporaries: Comparative Studies (Leiden: Brill, 1995), 419.

${ }^{77}$ Green mengatakan, "Jesus does not exercise his power as Messiah, Son of God to escape from death. Rather, Jesus exercises that power in unexpected ways; in obedience to God and in pouring out his life for others" ("Death of Jesus," 156).

${ }^{78}$ Dalam PL, pengurapan dengan minyak hanya dilakukan untuk orang-orang tertentu yang dipanggil untuk tugas/jabatan khusus seperti raja (1Sam. 9:15-16; 10:1; 16:3, 12-13; 24:6; 2Sam. 1:14) atau imam (Kel. 28:41; 1Taw. 29:22). Dengan demikian, kisah pengurapan Yesus ini secara tidak langsung menunjukkan bahwa Yesus adalah Mesias Rajani. Namun, pernyataan Yesus yang mengungkapkan bahwa pengurapan yang dilakukan perempuan itu merupakan persiapan untuk penguburan-Nya menegaskan bahwa Ia adalah Mesias yang menderita dan mati memberi
} 
dan sebaliknya, berupaya dengan kekerasan untuk melindungi Yesus (26:51-53). Mereka juga tidak konsisten dalam menunjukkan komitmen mereka kepada Yesus: tertidur di Taman Getsemani (26:40, 43); meninggalkan Yesus ketika Yesus ditangkap (26:56; bdk. $26: 35$; 20:22); dan bahkan menyangkal Yesus (26:69-75; bdk. 26:33-35). Sikap para murid ini sangat berbeda dengan sikap beberapa orang yang, melalui perbuatan mereka, menunjukkan dengan jelas karakteristik murid sejati, yaitu: perempuan yang mengurapi Yesus (26:6-13); perempuan-perempuan yang setia mengikuti Yesus dari Galilea (27:55-56, 61); dan Yusuf dari Arimatea (27:57-60). Mereka setia mengikut Yesus sampai akhir sekalipun dalam kondisi yang sulit.

Klimaks dari narasi ini terletak pada peristiwa kematian Yesus di kayu salib (27:45-50), yang mengakibatkan: pertama, tabir Bait Suci terbelah dua (27:51a); ${ }^{79}$ kedua, bukit-bukit batu terbelah dan kuburan-kuburan terbuka (27:51b-52a); dan ketiga, banyak orang kudus yang telah meninggal bangkit lalu masuk ke kota kudus dan menampakkan diri kepada banyak orang (27:52b-53). ${ }^{80}$ Melalui kematian Yesus dan berbagai peristiwa supranatural yang mengikutinya, Matius menunjukkan bahwa Kerajaan Allah dan keselamatan eskatologis yang awalnya disediakan bagi bangsa Yahudi, juga disediakan bagi bangsa-bangsa bukan Yahudi (bdk. 21:43). Hal ini dipertegas melalui pengakuan kepala pasukan dan para prajuritnya (tergolong bangsa bukan Yahudi)

hidupnya supaya bisa memberi kelimpahan hidup bagi semua orang (lihat S. Miller, "Anointing," dalam Dictionary of Jesus and The Gospels, ed. Joel B. Green, Jeannine K. Brown, dan Nicholas Perrin, ed. ke-2 [Downers Grove: InterVarsity, 2013], 17-18).

${ }^{79}$ Tabir Bait Suci terbelah dua mengindikasikan bahwa ritual-ritual PL tidak lagi diperlukan sehingga semua orang dapat datang kepada Allah dengan bebas. Hagner mengatakan, "The rending of the temple curtain ... foreshadows the end of the sacrificial cultus of the temple" (Matthew 14-28, 853).

${ }^{80}$ Bukit batu yang terbelah, kuburan yang terbuka serta bangkitnya orang kudus yang telah meninggal adalah simbol yang menunjukkan kepastian adanya kebangkitan orang mati di masa yang akan datang (ibid.). yang menyatakan bahwa Yesus adalah Anak Allah (27:54).

Matius melanjutkan narasinya dengan mencatat peristiwa mengenai gempa bumi (28:2), batu pintu kubur terguling (28:2), kehadiran malaikat (28:2-3) dan pernyataan malaikat bahwa Yesus telah bangkit (28:6). Matius ingin memperlihatkan bahwa peristiwa kebangkitan Yesus merupakan satu paket yang kontinu dengan peristiwa kematianNya, yang menunjukkan puncak kemenangan Allah yang menggenapi rencana eskatologisNya dengan menghadirkan Kerajaan-Nya di bumi ini. Dengan mencatat bahwa Yesus yang telah bangkit itu memiliki otoritas atas segala sesuatu (28:18), Matius ingin menunjukkan bahwa Yesus sekarang adalah representasi Allah secara universal. Yesus sekarang mengutus para murid-Nya bukan hanya untuk memberitakan injil Kerajaan Allah, menyembuhkan penyakit dan mengusir setan kepada umat Israel saja (bdk. 10:1-8). Dengan otoritas dan penyertaan dari Yesus (28:20), para murid sekarang diutus dengan tugas untuk menjadikan semua bangsa murid-Nya dengan cara mengajarkan mereka melakukan segala ajaran-Nya $(28: 19) .{ }^{81}$

Matius mengakhiri injilnya tidak dengan menceritakan peristiwa Yesus terangkat ke surga (Mrk. 16:19; Luk. 24:51; Kis. 1:9). Ia lebih menitikberatkan pada kehadiran Yesus yang terus-menerus menyertai para murid untuk tetap setia mengemban amanat memuridkan orang-orang lain. Di tengah keraguan yang bisa saja terjadi kepada para rasul (28:17) maupun komunitas murid-murid generasi selanjutnya ketika melaksanakan amanat Yesus, Matius ingin menegaskan bahwa ada kehadiran Yesus yang penuh kuasa serta janji firman-Nya yang terus-menerus menopang mereka. ${ }^{82}$ Dengan menutup injilnya yang berakhir pada perintah Yesus ini, Matius juga

\footnotetext{
${ }^{81} \mathrm{Di}$ sinilah pertama kalinya Yesus mengutus para murid-Nya untuk mengajar tentang Kerajaan Allah karena, sebelum perikop ini, mengajar tentang Kerajaan Allah adalah hak prerogatif Yesus sendiri (bdk. 4:23; 5:2; 7:29; 9:35; 11:1; 13:54; 21:23; 23:8; 26:55).
}

${ }^{82}$ Ulrich Luz, Studies in Matthew (Grand Rapids: Eerdmans, 2005), 134-135. 
ingin mengajak komunitas orang-orang percaya generasi selanjutnya yang membaca injilnya ini untuk bergabung bersama para rasul di kaki bukit menerima amanat pemuridan dari Yesus sehingga mereka bukan hanya sekadar diajarkan untuk menjadi murid melainkan juga memuridkan orang lain..$^{83}$

Jadi, dapat disimpulkan, Matius ingin menunjukkan bahwa, melalui Yesus, Allah telah menghadirkan Kerajaan-Nya di bumi ini, tidak hanya untuk bangsa Yahudi tetapi juga untuk bangsa-bangsa lain. Yesus sekarang mengutus para murid-Nya untuk menjadikan semua bangsa murid-Nya yang melakukan segala sesuatu yang Ia ajarkan. Dengan menjadikan semua bangsa murid Yesus berarti para murid telah menjadikan semua bangsa murid Allah yang melakukan kehendak Allah, sebab Yesus adalah representasi Allah dan ajaran Yesus merupakan penjabaran dari kehendak Allah.

\section{PEMURIDAN YANG BERDIMENSI KERAJAAN ALLAH}

Seluruh penjabaran narasi Injil Matius di atas memperlihatkan bahwa korelasi antara konsep Kerajaan Allah dengan pemuridan dalam Injil Matius adalah pemuridan merupakan proses mengikut Yesus sebagai muridNya dan juga menjadikan orang lain sebagai murid Yesus, dengan tujuan supaya semua manusia di bumi menjadi warga Kerajaan Allah yang taat melakukan kehendak Allah. Korelasi ini dapat menjadi sebuah kerangka kerja bagi pemuridan masa kini, yaitu sebuah pemuridan yang berdimensi Kerajaan Allah. Kerangka kerja yang dimaksud adalah pemahaman bahwa alam semesta ini ada di bawah pemerintahan Allah yang berdaulat melalui ketuhanan Yesus dan menuntut setiap manusia di bumi ini untuk taat kepada otoritas dan kehendak-Nya. Dengan demikian, pemuridan yang berdimensi Kerajaan Allah bercirikan theocentric commitment ${ }^{84}$ artinya sebuah

\footnotetext{
${ }^{83}$ Hannan, The Nature and Demands, 228.

${ }^{84}$ Istilah ini digunakan oleh Ben Cooper yang menyoroti Injil Matius sebagai bentuk communicative event yang menarik para murid dan orang-orang percaya lainnya untuk memercayakan hidup kepada Allah dan
}

proses memercayakan hidup sepenuhnya kepada Allah dalam wujud bertobat dan percaya kepada Yesus yang telah menghadirkan Kerajaan Allah tersebut, berkomitmen untuk meneladani karakter-Nya dan menghidupi ajaran-Nya serta ikut berpartisipasi di dalam pekerjaan Kerajaan Allah yang Ia kerjakan dengan membimbing orang-orang lain untuk menjadi murid-Nya juga.

Pemahaman yang benar terhadap hal ini akan menghasilkan komitmen yang solid dan kuat dari setiap orang Kristen di dalam mengikut Yesus. Komitmen ini diwujudkan dengan pertama, menjalani hidup sesuai dengan identitas mereka sebagai warga Kerajaan Allah yang memegang teguh nilai-nilai Kerajaan Allah sebagai wujud ketundukan kepada pemerintahan Allah dan ketaatan kepada kehendak Allah, Sang Raja. Implikasi logis dari hal ini adalah kehidupan orang Kristen tidak akan bermental escapist (menarik diri dari realitas kehidupan dan tidak peduli terhadap kondisi dunia ini), melainkan "menggarami" dan "menerangi" dunia ini dengan nilai-nilai Kerajaan Allah. Kedua, komitmen mengikut Yesus tersebut juga diwujudkan dengan melaksanakan tugas pemuridan yang menjadi tanggung jawab setiap orang percaya. Pengikut Yesus bertanggung jawab untuk melipatgandakan dirinya, dalam arti kembali menghasilkan murid yang juga memiliki komitmen yang solid dan militan kepada Yesus. Dengan demikian, penginjilan dan pemuridan adalah dua hal yang tidak terpisahkan.

Orang-orang Kristen dengan kualitas seperti yang dijabarkan di atas hanya dapat dihasilkan dari sebuah pemuridan yang dilakukan di dalam dimensi Kerajaan Allah. Oleh karena itu, ada beberapa hal yang harus diperhatikan di dalam pelaksanaan pemuridan. Pertama, pemuridan harus memiliki tujuan utama agar semua orang di muka bumi ini tunduk kepada pemerintahan dan otoritas Allah, yang dinyatakan dengan ketaatan melakukan kehendak

berpartisipasi dalam menyatakan keselamatan atas bangsa-bangsa dengan mengikuti jalan kerendahan hati dan perhambaan seperti yang telah Yesus teladankan sebagai hamba TUHAN versi nabi Yesaya (Incorporated Servanthood, 252-256). 
Allah yang dijabarkan di dalam setiap ajaran Yesus. Pemuridan bukan hanya sekadar salah satu aktivitas/program dari sekian banyak aktivitas/program lainnya; melainkan pemuridan adalah pusat dan fokus dari berbagai aktivitas/program yang dikerjakan. Kedua, pemuridan berfokus untuk membina setiap orang Kristen agar dapat menghidupi identitas mereka sebagai warga Kerajaan Allah, atau dengan kata lain memiliki karakteristik murid seperti yang diajarkan Yesus di dalam seluruh Injil Matius: kerendahan hati, iman dan ketaatan kepada kehendak Allah yang lahir dari hati yang mengasihi Dia dengan sepenuh hati serta diwujudkan dalam perbuatan baik mengasihi sesama seperti diri sendiri. Ketiga, proses pemuridan tidak hanya berhenti sampai memanggil dan membimbing seseorang untuk menjadi murid Yesus, melainkan juga menjadi murid yang memuridkan orang-orang lain lain juga.

\section{KESIMPULAN}

Artikel ini telah menguraikan secara detail korelasi antara konsep Kerajaan Allah dengan pemuridan dalam Injil Matius serta signifikansinya bagi pemuridan di masa kini. Korelasi ini memberikan fondasi bahwa proses pemuridan harus dilakukan dalam kerangka menjadikan semua orang percaya hidup sebagai warga Kerajaan Allah yang tunduk di bawah pemerintahan Allah dan taat melakukan kehendak-Nya. Pemuridan yang dilaksanakan di dalam dimensi Kerajaan Allah ini akan menghasilkan orang-orang Kristen yang memiliki komitmen yang solid dan militan dalam mengikut Yesus, yang diwujudkan dengan hidup berdasarkan nilai-nilai Kerajaan Allah dan melaksanakan pemuridan yang menjadi tanggung jawab mereka. Untuk itu, ada tiga hal yang harus diperhatikan di dalam melaksanakan pemuridan, yaitu: pertama, pemuridan harus memiliki tujuan yang memenuhi maksud kehadiran Kerajaan Allah di bumi ini; kedua, pemuridan harus berfokus membina setiap orang Kristen agar hidup sesuai dengan nilai-nilai Kerajaan Allah; dan ketiga, proses pemuridan harus mencakup tiga hal, yaitu pemanggilan murid, pembinaan murid, dan pelipatgandaan murid.

\section{DAFTAR KEPUSTAKAAN}

Bacon, Benjamin W. "The Five Books of Matthew Against the Jews." Expositor 15 (1918): 56-66.

\section{0.}

Barna Group. "New Research on the State of Discipleship." Barna Group. Diakses 1 Juni 2019. https://www.barna.com/ research/new-research-on-the-state-ofdiscipleship.

Calvert, Nancy L. "Abraham." Dalam Dictionary of Jesus and The Gospels, diedit oleh Joel B. Green, Scott McKnight, dan I. Howard Marshall, 3-7. Downers Grove: InterVarsity, 1992.

Cooper, Ben. Incorporated Servanthood: Commitment and Discipleship in the Gospel of Matthew. Library of New Testament Studies 490. New York: Bloomsbury, 2013.

Donaldson, Terence L. "Guiding ReadersMaking Disciples: Discipleship in Matthew's Narrative Strategy." Dalam The Pattern of Discipleship in the New Testament, diedit oleh Richard N. Longenecker, 30-49. Grand Rapids: Eerdmans, 1996.

Ellis, Peter F. Matthew: His Mind and His Message. Collegeville: The Liturgical, 1974.

Evans, Craig A. Jesus and His Contemporaries: Comparative Studies. Leiden: Brill, 1995.

France, R.T. Matthew: Evangelist \& Teacher. Exeter: Paternoster, 1992.

- Yesus Sang Radikal: Potret Manusia yang Disalibkan. Diterjemahkan oleh P.G. Katoppo. Jakarta: Gunung Mulia, 2004.

Glasser, Arthur F. Announcing the Kingdom. Grand Rapids: Baker, 2003. 
Green, Joel B. "Death of Jesus." Dalam Dictionary of Jesus and The Gospels, diedit oleh Joel B. Green, Scott McKnight, dan I. Howard Marshall, 146-163. Downers Grove: InterVarsity, 1992.

" "Kingdom of God/Heaven." Dalam Dictionary of Jesus and The Gospels, diedit oleh Joel B. Green, Jeannine K. Brown, dan Nicholas Perrin, 468-481. Ed. ke-2. Downers Grove: InterVarsity, 2013.

Hagner, D.A. Matthew 1-13. Word Biblical Commentary 33a. Dallas: Word, 1993.

- Matthew 14-28. Word Biblical Commentary 33b. Dallas: Word, 1993.

Hannan, Margaret. The Nature and Demands of the Sovereign Rule of God in the Gospel of Matthew. Library of New Testament Studies 308. New York: T\&T Clark, 2006.

Hull, Bill. Building High Commitment in a Low Commitment World. Grand Rapids: Revell, 1995.

Keener, Craig S. The IVP Bible Background Commentary: New Testament. Downers Grove: InterVarsity, 1993.

The Gospel of Matthew: A Socio-Rhetorical Commentary. Grand Rapids: Eerdmans, 2009.

Kingsbury, Jack Dean. Matthew as Story. Philadelphia: Fortress, 1986.

- Matthew: Structure, Christology, Kingdom. Minneapolis: Fortress, 1989.

—. "The Plot of Matthew's Story," Interpretation 44, no. 4 (1992): 347-356.

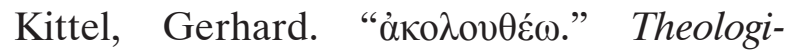
cal Dictionary of the New Testament vol. 1, diedit oleh Gerhard Kittel, 210-216. Grand Rapids: Eerdmans, 1964.

Loader, William. Jesus and The Fundamentalism of His Day. Grand Rapids: Eerdmans, 2001.
Luz, Ulrich. The Theology of The Gospel of Matthew. Cambridge: Cambridge University, 1995.

. Matthew 8-20: A Commentary. Augsburg: Fortress, 2001.

- Studies in Matthew. Grand Rapids: Eerdmans, 2005.

Meier, John P. "Matthew, Gospel of." Dalam Anchor Bible Dictionary Vol. 4, diedit oleh David Noel Freedman, 622-641. New York: Double Day, 1992.

Miller, S. "Anointing." Dalam Dictionary of Jesus and The Gospels, diedit oleh Joel B. Green, Jeannine K. Brown, dan Nicholas Perrin, 17-18. Ed. ke-2. Downers Grove: InterVarsity, 2013

Morris, Leon. The Gospel According to Matthew. Pillar New Testament Commentary. Grand Rapids: Eerdmans, 1992.

Pennington, Jonathan T. Heaven and Earth in the Gospel of Matthew, Novum Testamentum Supplement 126. Leiden: Brill, 2007.

Schnackenburg, Rudolf. The Gospel of Matthew. Grand Rapids: Eerdmans, 2002.

Smith, Christopher R. "Literary Evidence of a Fivefold Structure in the Gospel of Matthew." New Testament Studies 43 (1997): 540-551.

Weren, Wilhelmus J.C. Studies in Matthew's Gospel: Literary Design, Intertextuality, and Social Setting. Biblical Interpretation Series 130. Leiden: Brill, 2014.

Wilkins, M.J. "Disciples and Discipleship." Dalam Dictionary of Jesus and The Gospels, diedit oleh Joel B. Green, Jeannine K. Brown, dan Nicholas Perrin, 202-212. Ed. ke-2. Downers Grove: InterVarsity, 2013.

"Temptation of Jesus." Dalam Dictionary of Jesus and The Gospels, diedit oleh Joel B. Green, Jeannine K. Brown, dan Nicholas Perrin, 952-959. Ed. ke-2. Downers Grove: InterVarsity, 2013. 
Willard, Dallas. "Rethinking Evangelism." DWillard.org. Diakses 1 Juni 2019. http:// www.dwillard.org/articles/individual/ rethinking-evangelism.

Witherington III, Ben. "Birth of Jesus." Dalam Dictionary of Jesus and The Gospels, diedit oleh Joel B. Green, Scott McKnight, dan
I. Howard Marshall, 60-74. Downers Grove: InterVarsity, 1992.

Young, S. "Birth of Jesus." Dalam Dictionary of Jesus and The Gospels, diedit oleh Joel B. Green, Jeannine K. Brown, dan Nicholas Perrin, 72-84. Ed. ke-2. Downers Grove: InterVarsity, 2013. 